\title{
الشبكة العنكبوتية ودورها في نشر الدعوة الإسلامية
}

إعداد : د. أحلام عبد الرحيم أحمد مصطفى

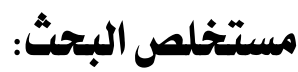

الحمد لله رب العالمين والصلاة والسـلام على سيدنا محمدد وعلى

آله وصحبه وسلهم، يهدف هذا البحث إلى كيفية الاستفادة من الأنترنت للدعوة الإسلامية والاستفادة من هذه الوسيلة الحسلة الحديثة التي لها تأثير

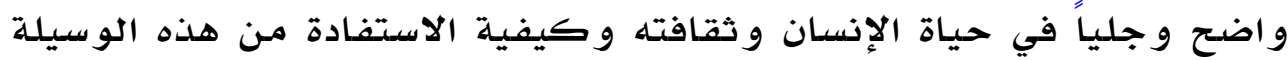
في نشر الدعوة ووصول صوت الدعاة إلى جمهور كبير من الناس.

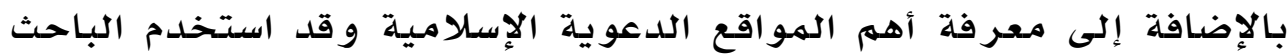

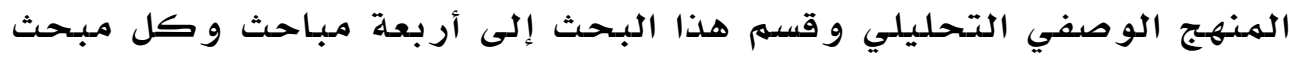
يحتوي على ثلاثة مطالب. وختتم هذا البحث بوصئم وهايا عديدة من أهمها الاهتهام بهذه الوسيلة وتسخير ها لأمر الدعوة الإسـلاميلة.

\section{Abstract}

Praise be to Allah, Lord of the Worlds, and prayers and peace be upon our prophet Mohammad and his family and companions. Praise be to God, Lord of the Worlds, prayers and peace be upon our master Mohammad, and his family and companions. This research aims at how to take advantage of the internet for the Islamic Da'awa and to benefit from this modern means that has a clear and obvious impact on human life and culture, and how to benefit from this means in spreading the Da'awa and reaching the voice of preachers to a large audience of people. In addition to identify the most important Islamic Da'awa sites, the researcher used the descriptive analytical method and divided this research into four chapters, and each chapter contains three topics. This research concluded with several recommendations, the most important of which is the pay attention in this mean and harnessing it to the Islamic Da'awa.. 
في هذه الأيام أصبـح الجميع يستخدلم أجهزة الكمبيوتر ، فقد حلـت محل الآلات الكاتبـة ومستتندات الأرشيف ، بل دخلت محل الألعاب التقليديـة لكلأطفال في المنازل ، و أصبـحت أسـاسية في تصهيهم المنشـآت و البر مسجيات.

ومنذ أن ظهرت العلاقات التي تربط تقنية الكمبيوتر بتقنيـة الاتصــالات ، أخذت أهميـة الكمبيوتر تتزايد ، وأصبـحت مححلات استخدامـه أوسـع •

إلا أن أبرز مـا ينتج عن هذه العلاقة كان ظهور شبكة إنترنت أدى التطور الهائل الهشاريع في تكنولوجيا الاتصسال في نهايـة هذا القــرن ، إلـى إنتــاج و سـائل حديثة في التواصل الاجتهماعي ،عملت على تغيير أنماط حياة الأفراد اليوميـة ، و علاقتاهم التقليديـة الهـألوفـة ، و يــأتي الإنتر نـت فـي مقدمــة

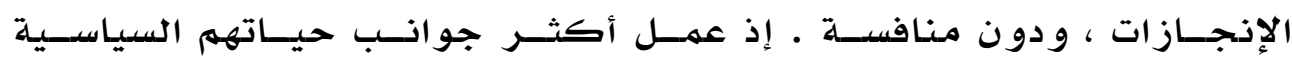
و الاجتمـاعية و النفسية ....

كما أنه عمل في الوقت نفســه عمـالاً و اضــحاً وجليــاً فـي طبيعـة الاتصسالات الأخرى التـي تعـود عليهـا الهـجتهــع ، وشـبـه بعـض البــاحثين التغير ات ، و التأثيرات التي أحدثها الإنتر نـت فـي حيـاة النـاس وثقــافتهم بتلك التي أحدثها فيهم التلفون في مطلع العشـرينيـات و التيلفزيــون فـي مر حلة الخمسسينات و الستينات1991ام و تشبيـه لقوة هذه التغيـر ات إلـى أبعـد من ذلك'

\section{أهمية المورضوع :}

نسبـة لتطور شبكة الإنترنت في أنحاء العالم وووصو لها إلـى الـبـلاد

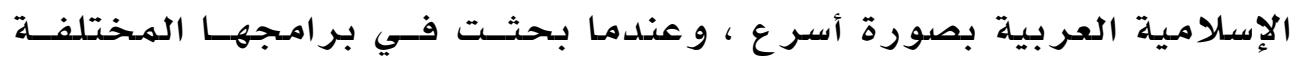
و جدت أن هناتك مواقع إسلامية كثيرة جداً قام ببثها أخوة دعاة إسلالميون

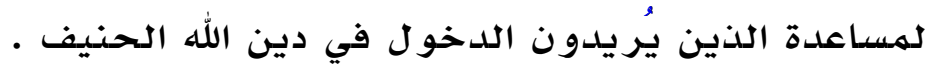

' - مصطفى السيد ، دليلك 'لى شبكة الإنتر نت ، طم ؟.بrم ، النشر القاهرة ، ص9. 


\section{أهداف البحث : يهدف البحث إلى:}

$$
\begin{aligned}
& \text { 1) معرفة المهواقع الدعوية الإسلاميلة. }
\end{aligned}
$$

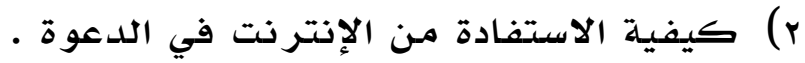

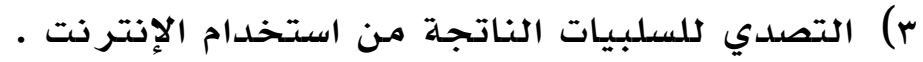

مشكلة البحث :

$$
\begin{aligned}
& \text { تتمثل في كيفية الاستفادة من مقاهي الأنترنت فـي نشـر الــدعوة } \\
& \text { الإسسلا ميـة. }
\end{aligned}
$$

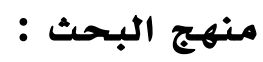$$
\text { الهنهج الوصفي التحليلي. }
$$$$
\text { أدوات البحث : n l n }
$$$$
\text { الاستبانة. }
$$$$
\text { تبويب البحث : }
$$$$
\text { ( ) المبـحث الأو ل مفاهيم و مـزايا و أضرار الإنتر نت }
$$

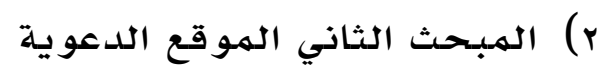

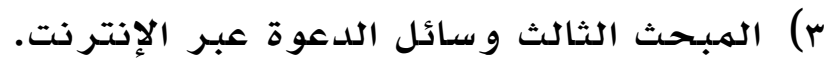

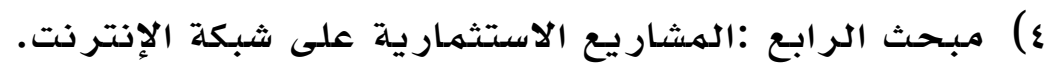

الخخاتمـة وتشهـل

$$
\text { ب. أ. النتائج . }
$$

\section{المبحث الأول : مفاهيم ومزايا وأضرار الإنترنت}

\section{الاطلب الأول : مفهوم الأنترنت :}




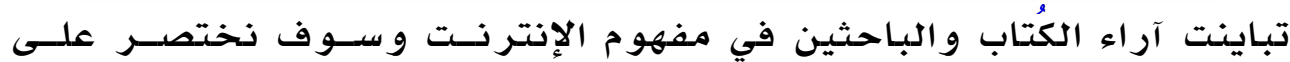

بعض الباحثين يرى في مفهومها أنه نظام منتتشر في جهيـع أنحـاء العـالهم

ويتألف من الآتي :

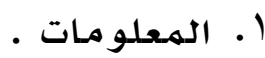

ץ. حواسيب : وهي تعتبر مُعوقة للرجة يصعب فهمها للإِنسـان والتـي

بـوروها تؤدي إلى صعوبـ فهم الإنتر نت . ووفـي الحقيقــة لا يوجسـ

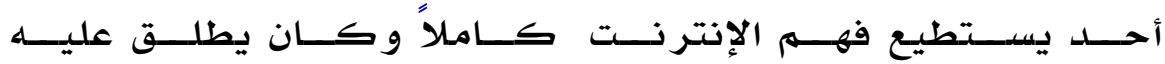

ARPANET

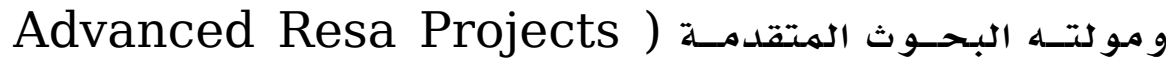

لوزارة الــدفاع الأمـريكيــة التـي أهتهــ (Age hchcy:ARPA ببنـاء شبكة يمكـن أت يـتهم مـن خلالهـا نقـل المعلومــات حكوميـة

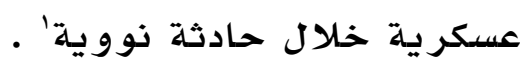

و يرى هذا البـاحث الآخر أن الإنتر نت يطلق على مؤلفه مــن حاسـبـ

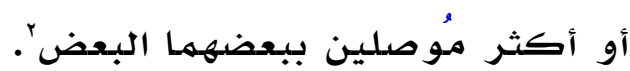

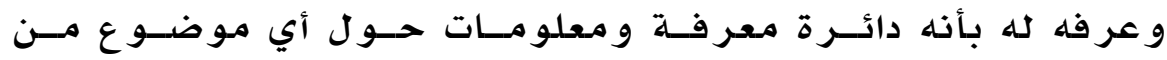
الهـوضوعات التي يحتاجونها ، سواء كانت على شكل نص مكتوب أو مـرسوم أم على ثـكل خر ائط ، أو كان ذلك عـن طريـق التراسـلـ بواسطة البر يـد الإلكترو ني ، و تضمى تلك الدائرة العمهلاقة الملايـين

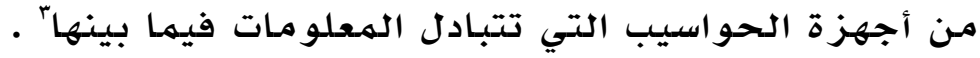
و هو أيضاً عر فها : بأذها وسيلة اتصال حديثة تتألف مسـن مسجموعـة مـن الحواسيب الهـرتبطة في شبكة أو شبكات كثيرة . توفر كثيـر

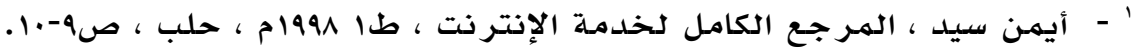

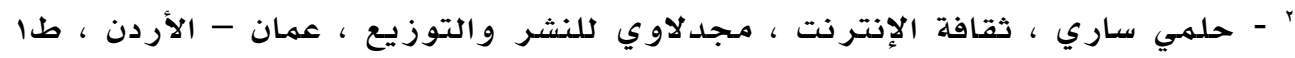

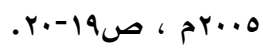
r - مصطفى السيد ، دليلك إلى شبـة الإنترنت ، مرجع سابق ، صلالـ 
من الحواسيب و الخدمات و تسـهـح بالتنقـل بطريقــة واحسدة بـين

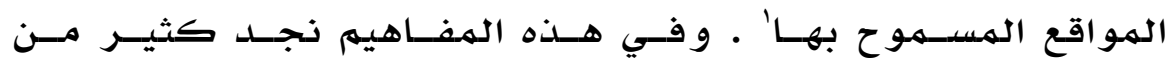

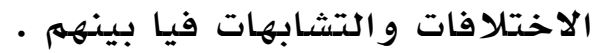

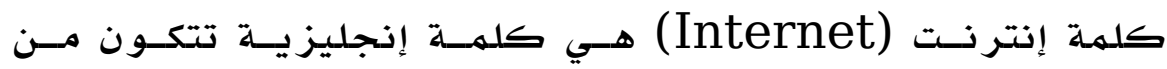
جز أين:

$$
\text { الجزء الأول : (Inter) و ويعني (بين). }
$$

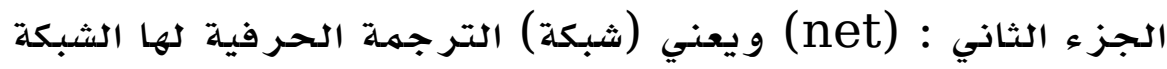

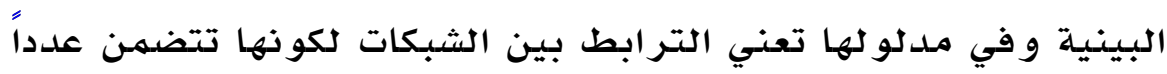

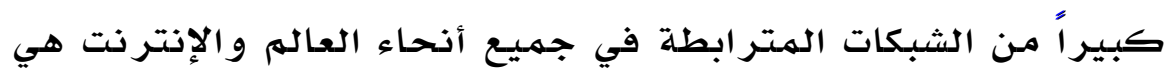

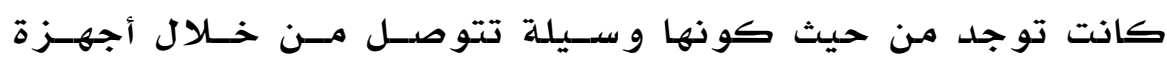

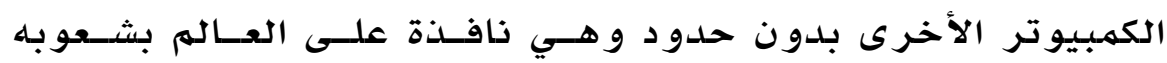

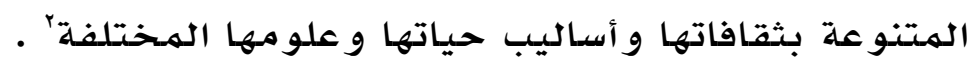

الاطلب الثاني : خصائص ومزايا الإنتزنت :

وسوف نختصر على أهم الهزايا والخصائص وهي :

1. يعتبر النت أكثر حداثة و تطوراً من أشكال الاتصال .

r. بكل من أشكال التكنو لوجيا.

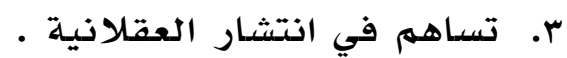

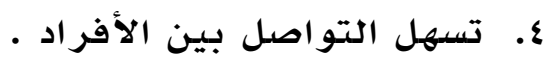

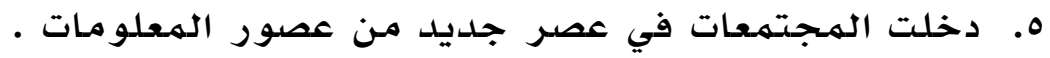

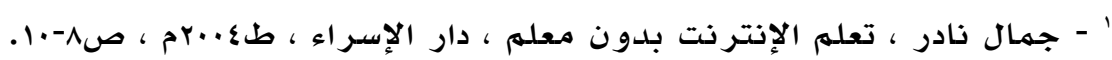

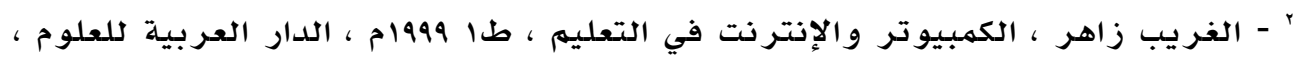
صמrro 
فوسائل الاتصـال هي في الواقع مؤسســات ضـخمـة تسـتند إلـى قاعـدة

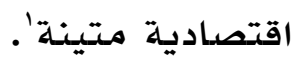

\section{و كذلك من الخصائص و الهميزات :}

ا. تعدد الوسـائط التي يستخدمها الإنترنت أي (دمـج الصـور و الأفــلام

$$
\text { و الر سوم الهتحر كة و الصوت) . }
$$

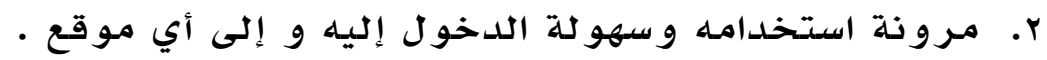

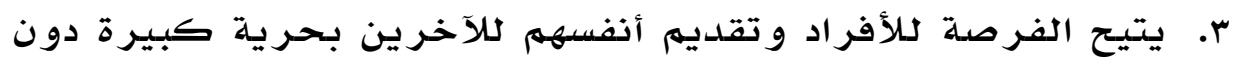

$$
\text { قيو د. }
$$

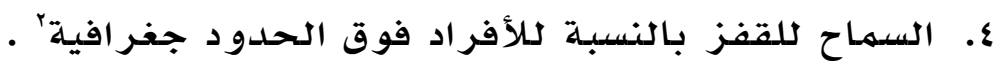

$$
\text { المطلب الثادث : أضرار الإنترنت : }
$$

الإنتر نت كغيره مـن الوسائل الحديثة له منافع و أضـرار فهـذه الأضـرار ، إمـا أن تكون أخلاقيـة ، ثقافيـة ، اجتمهاعية ، واقتصـادية ، إمـا أن تكـون غيـر ذلك.

\section{أو لاً : اللدخول إلى الأماكن المهنوعة :}

إن الأمسن الاقتصسادي من أهم الهبـادئ التي تؤكد عليها الهؤسسـات الحكومية بجميـع أشكالها و أحجامها ، و أنواعها بل أن أهدف الدو ل العظهـى ، تــوفير

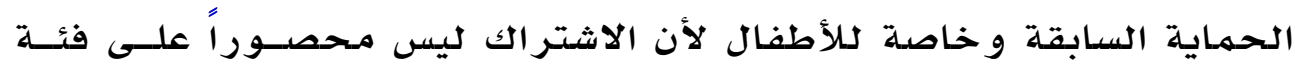
معينة مثقفة وو اعيـة للاستخدام و مدرركة لهر اوغات النصسب و الاحتيـال ، و الدخو ل على بعض الهـواقع التي تدعو إلى الرزيلة و نبـ القـيهم والهبــادئ و الأخلاق

\section{: نانياً : الأمن الفكري}

' - مصطفى السيد ، دليلك إلى شبكة الإنترنت ، مرجع سابق ، صالr-rV.

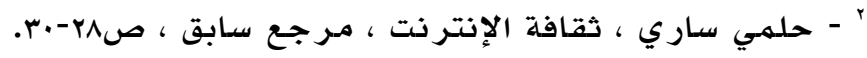


أحد الهقومات الأساسية لصلاح المجتمعات والدول لكننـا في عصـر

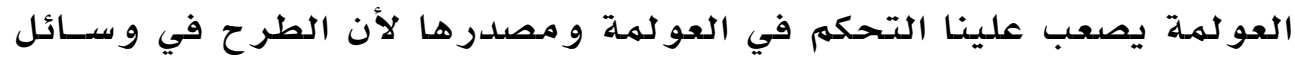

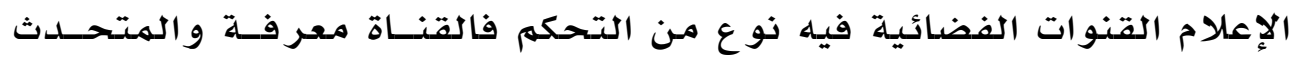
معرو ف عكس الإنتر نت:

حيث يمكن أن تشتر ك منظمات إرهابيسة وأثـخـاص حاقـدون علـى

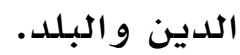

\section{: ثالثاً : الأضرار الثقافية :}

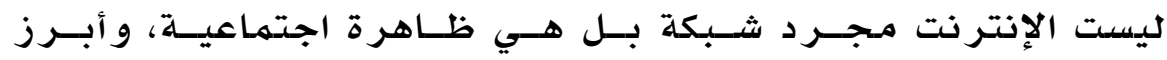

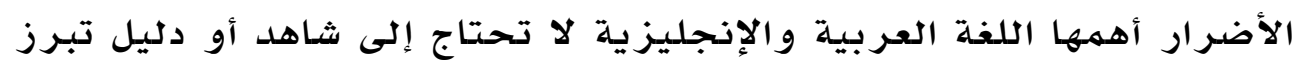

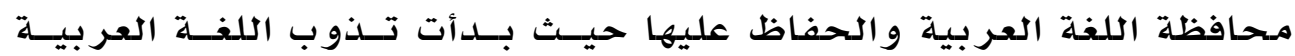

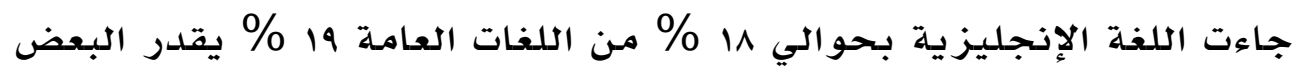

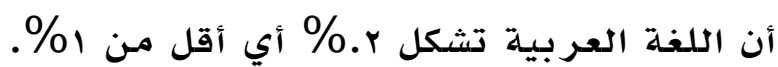




\section{رابعاً : اللدقة والمسراحة :}

من أهم الأضر ار فليس كل ما يكتب في الإنتر نت صحيح ودقيق ذلـك أن معدر المعلومـات أحياناً غير واضتح فتتأثر وتشوه في أفكار الشبـاب الأمـر الذي يدعونا إلى التدريب في نقل الأخبار كها تجدر الإشارة إلـى قضـية تحريف بعض المـواقع وخاصدة الإسلاميلة عندما تخترق من الأعداء.

\section{خامساً : الأخرار الاقتمسادية :}

الإنترنت سلاحح ذو حدين فكما أن يكون لها جوانب إيجابية يكون له جوانب سلبيـة. بعض الشركات لها أضرار عكسية و تتهثل هذه الأضرار فـي وضـع الشرركات مـواقع لها عبر البيانات غير آمنـة الأمـر الذي ســاعد الهـخـرجين للدخول على هذه الهـواقع الههمة وتدمير بياذـات الشـر كات او التحريـف فيها وخاصـة إذا كان هنــاتك تنـافس بــين الشـر كات ولهــا أضــرار علـى الشركات و الدول التي لهم تجاري السير في هذه التقنية.

و لها أضرار شخصية في الهضدايقات بسبب الر سـائل سواء كانت دعائيــة أو إعلانية، أو إعلان أو إهدار الوقت بكثرة تصفح ما لا يغني و لا يسـهـن مــن جوع هنالك أكثر مـن خدعة قد تعرف الشاب بها وقد انخدع منها :

خدع الهـال السهل ، خدع الحصول أكثر دون مقابل ،خدع الفوز بالجــائزة

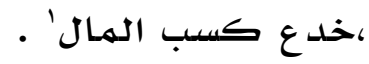

' - عبدالله بن عبدالعزيز الموسى ، مقدمة في الحاسب والإنترنت ، مرجع سـابق ، صטגדי-יטים 
btto.//www sahwahnet/sahwah/for http://www,sahwah.net/sahwah/forumd.ulphp?forumid=6

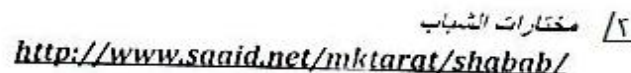

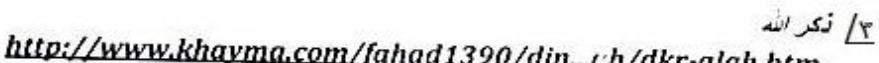

htipi//www khayma.com/fahad1390/din.ush/dkr-alah.htm

$$
\text { 洗 }
$$

httpi//www,khayma.com/nuzhatalmutagin/mohasaba/

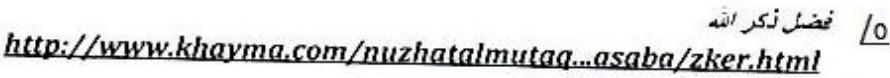
المابط رومراجي عن الدعاء http://www heartsactions.com/ref/bphtm

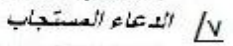
httpi//konouz.com/eldoaa/

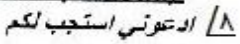

http://wwwaltqwa.8m.com/d3a-mstiab.html

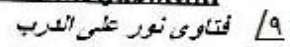

http://www binbaz,org.sa/Treeasp?ID=218t=bab6

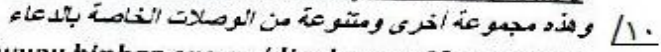

httpi//www.binbaz.org.sa/display,asp?f=eng0084

$$
\begin{aligned}
& \text { \11 موتع امراض "اقتوب للدكتور ناد "جبيير } \\
& \text { hitp://www heartdes.com/ }
\end{aligned}
$$

http://wwwhome4arab.com/members//iwislam5/sitehtm Mr

$$
\text { httpi//wwwkhayma.com/alvubroodi/mushtagoonhtm }
$$

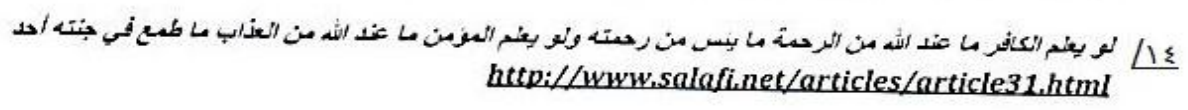

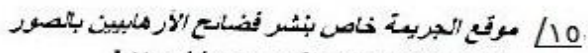

$$
\begin{aligned}
& \text { http://www.aliareemah.org/ }
\end{aligned}
$$

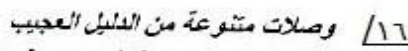

$$
\begin{aligned}
& \text { hctp://www.alajeeb.com/alajeeb 5.shtml } \\
& \text { "آس IV } \\
& \text { hto://wwwnk1.net/story.htm }
\end{aligned}
$$




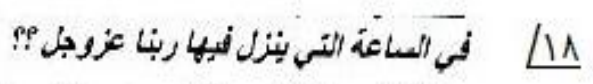

http://wwwnk1.net/story5.htm

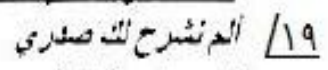

http://alajeeb.com/alajeeb.swf

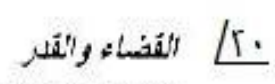

http://wwwalminbar.cc/alkhutab/khump? mediaURL $=3272$

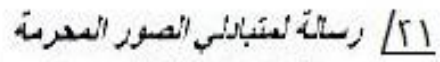

$$
\begin{aligned}
& \text { لتحميل "لبرنامتج }
\end{aligned}
$$

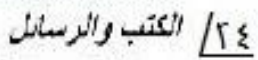

ttp://www.khayma.com/alshabab/ktoob\%20and\%20rsael.htm

h

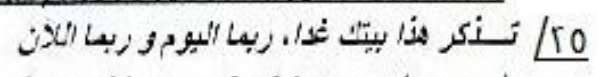

httpi//www.dotbint.net/come/

http://wwwdotbint.net/come/nazem.htm

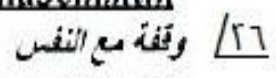

http://wwwanjad.com/islam/

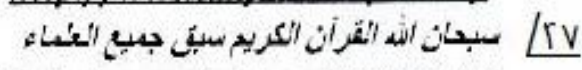

http://alajeeb.com/subhan\%20Allah/

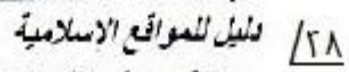

http://www.ravig.com/links/isalam.htm

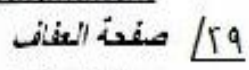

httpi//dr-mmb.tripod.com/afaf.hem

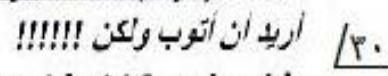

http://www.islamway.com/bindex?sect..ld $=44 \&$ series id

$$
\text { عواتى الاستقامة }
$$

http://wwwislammemo.com/lessons maw/lessons $12 . h t m$

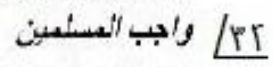

http://alarabnews.com/alshaab/Books/Book14.htm 


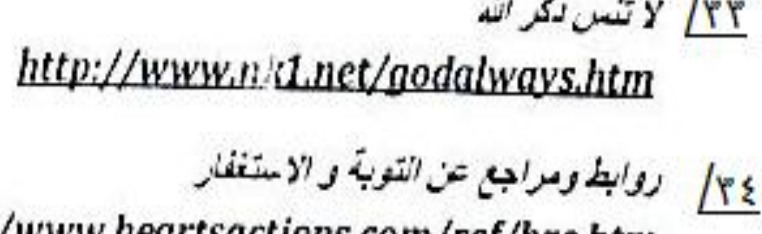

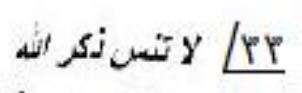
http://wwwheartsactions.com/ref/bre.htm

http://wwwislammessage.com/ar/indexphp

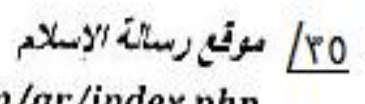

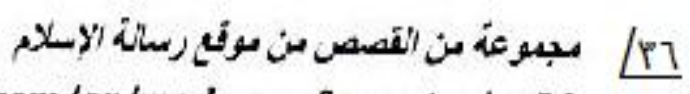

http://wwwislammessage.com/ar/modu..ws \& new topic $=30$

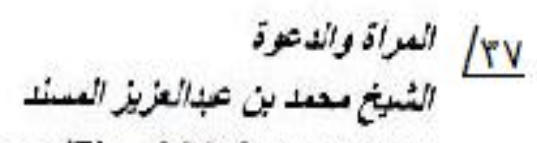

http://wwwlahoonline,com/Daawa/Fiq, 002,doc crthtm

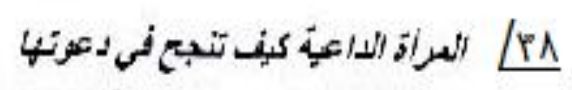

http://www.saaid,net/female/18.htm

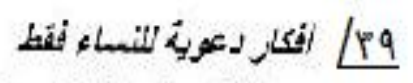

bitpi//wwwsaaidnet/female/indexihtm

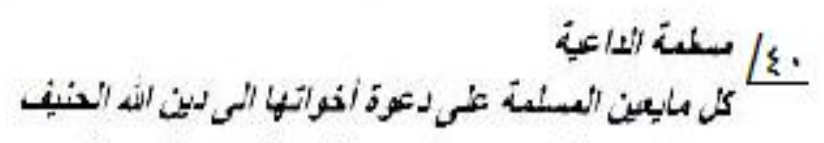

http://muslema.com/muslema/topics.p...ewtopic\&topic=9

$$
\text { 年 }
$$

http://www.naseh.net/d3oh/d2.htm

http://www.enshad.net/intaag/Islamic Cassette Center/ مركز الشريط الولاسم 


\section{ثانياً: الوصف العام للموقع :}

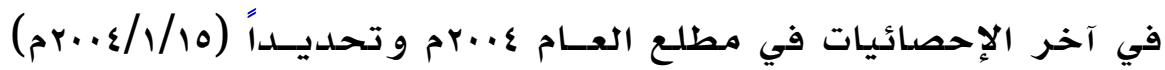

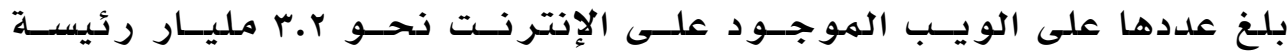

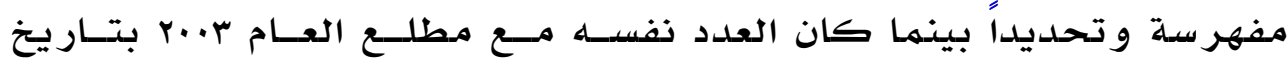

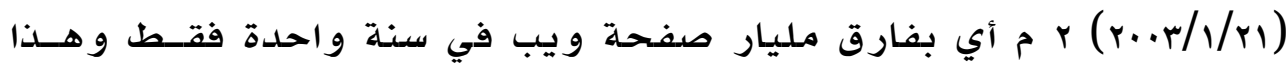

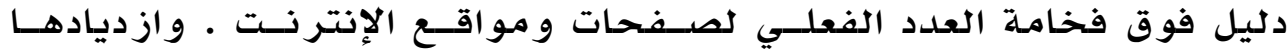

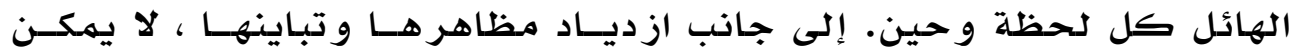
و صفه على و جها جديد.

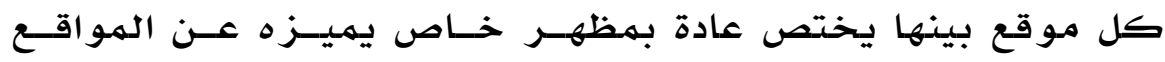

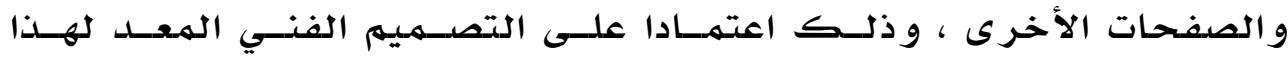

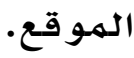

و يضمن ذلك اسم الموقع أو الصفحة و غاباً مــا يكسون اســماً يــدل

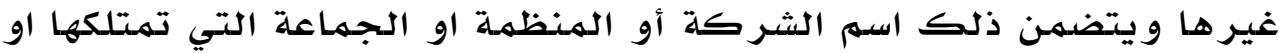

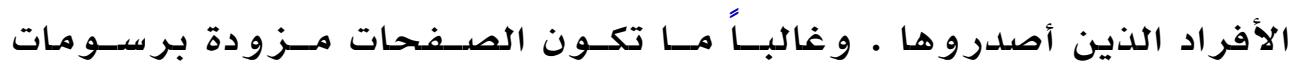

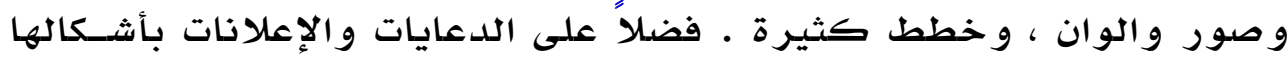
الهختلفة و الوصور واتلات و والرو ابط بالهموقع .

والشركات الدعوية الهتخصصة في تقديه الخسـدمات تمثـل أشـهر

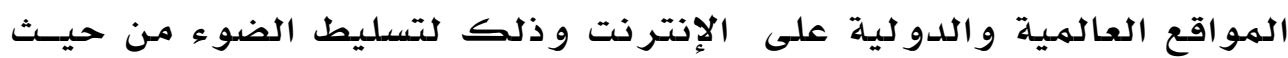

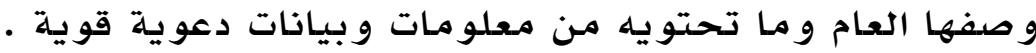

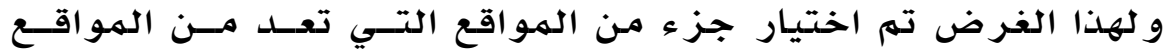

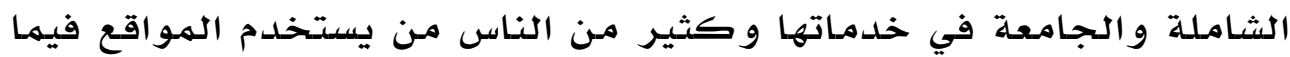
يرضي الله ور سو لكه . 
و النظر إليها بشكل عام حتى يتهكن إيضاح الصدور العامـة لهذا الهوقع علهاً

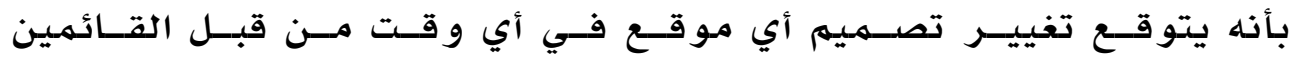

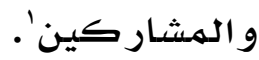

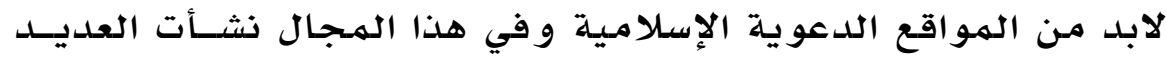
من الهمواقع الدعوية ، مثثل عمرو خالد وعمـرو مـوسى ، و مصطفى حســي ، و غير هم مـن الدعاة. والآن قامت معظم الشر كات التي تـهم نشـاطها ذلــك على خدمهة القطاع التجاري وتقديهم الدعايـة • و مـع ذلك نشأت بعض التـي أدخلت مواد تثقيفية و معارف دينية عربية إلى الشبكة وتـهم إنثـاء مـواقـع عربية شـاملة يحتوي على مسختلـف المعلومسات الخـاصسة بالعـالهم العربـي و الدول الأخرى .فالأمور تتطور بسرعة أكبر منها فـي الحيــاة الحقيقـة فقد تطور الإنتر نت مـن مـجرد و سـيلة جامسدة لنشــر المعلومــات لوسـيط

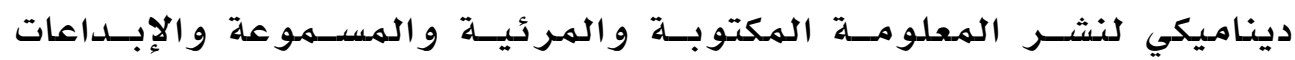

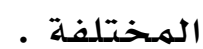

و مـن العوامل الأسـاسيـة التي سـاعدت في إعطاء زخــهم هائـل توفر هــا مجاناً فترة طويلة في المؤسسات ، ثه أسعار زهيدة جداً في ككل مكـان . و الدوول تستهمر في إنشاء الهـواقع ونقل الخدمات وتحقيـق أهـــاف دعويــة إسلامية تسـاهم في انتشار الدعوة الحديثة' .

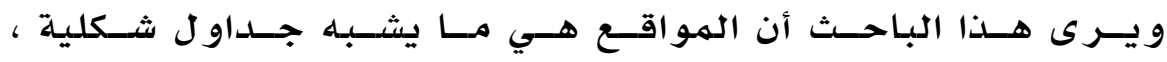
و تنسيقات عامهة بين هيكلها الهعلوماتي ، و عليك أن تفـتح الهموقـع الـذي تر يده و الذي يتعلق ويرتبط بهـوضو عك ، وبإمكان الشخص و الذي يتعلـق و يرتبط بتكييف الموقع على نسق ملائم له ، و ذلك حسب رغبـة الهستخدم

' - علي محمد رحومة ، الأنتر نت و المنظومـة التكنو إجتماعية ، طا يوليو ه+بrم ، النشر

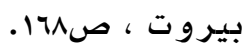
' - علاء الدين عبد الرزاق وحسين عبد الرزاق ، شبكات الإدارة ، دار وائل للنشر

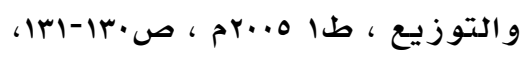


و تسهيلات التقنيات التي تقدمها عادة مثل الهواقـع الشــاملة . و يجعـل لــــ موقع دعوي من قبل الدعاة و الشيوخ الهعروفين ذوي الهمواقع الهعروفة'. : شبكة ومنتديات الإسلام نلجميع http//www/is/s/amiczall.com/sound/show/maingpeg (ehtm

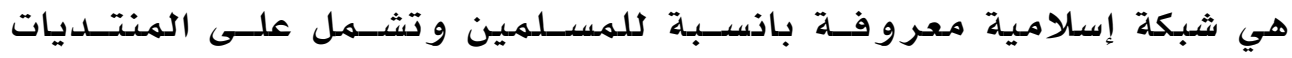
الإســلامية و الهـرئيـات و الهــوتيات الفتـاوى ، و الهقــالات ، و الهنــاظر ات ، و السهمعيات ، و غيـر هـا.

و هي شبكة دعويـة وتحتوي على الكثير من ذلك : و هي مـا يلي : (ا/القر ان الكريم ب/ قسم الإذاعة ب/ قسم الرقية الشر عية ع/ قسم الأناشـيد ه/ قسم الدروس و الخطب الصوتية ج/ صوتيات متنوعة). و سنتححدث عن كل و احدة ومنها بإيجاز : أو لاً القران الكريهم :عدد القراء : 109 قارئ عدد السـور عال سـورة أنسواع

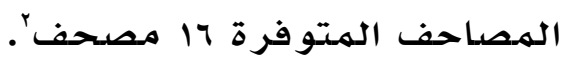
: ثانياً : قسم الأدعية :

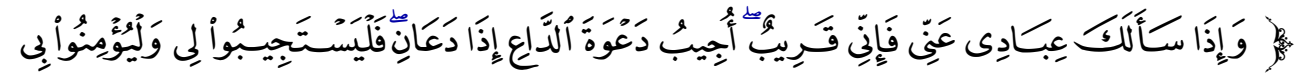

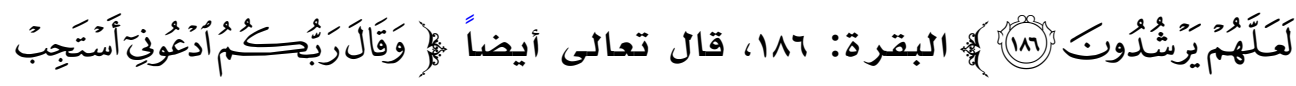
' - علي محمد رحو مـة ، الإلإنتر نت و المنظومـة التكنو إجتماعية ، مـرجع سابق ، ص 179. http//www:mpr.guran-net - r 


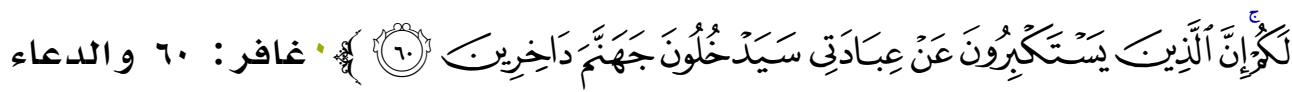
يكون من الأدنى إلى الأعلى.

و يكون الإنسـان قريباً مـن الله إذا كان سـاجداً فيـدعوا كيـف يشــاء وكثير مـن السور التي وجد فيهـا دعـاء ، ســورة البقـرة ، و آل عمــران ، و غافر ، و غير هـا .

وجاءت كثير من الأدعيـة مثـل أدعيـة أذكـار المســاء والصــبـاح فنذكر من الأدعية (أذكار الصبـاح والهسـاء). كان النبي صسلى الله عليـهـ

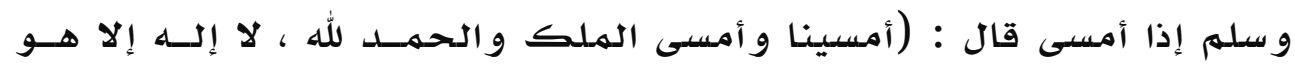
وحده لا شـريك لله الهلك و له الحمدل وهو علـى كـل شــيء قـدير ، رب أسألك خير ما في هذه الليلة ، وخير ما بعدها ، و أعوذ بك من شر هــذه

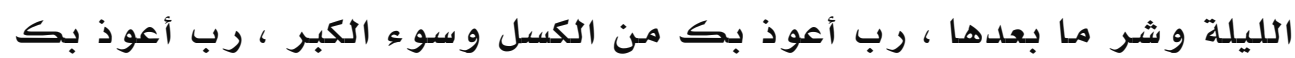

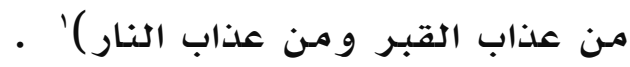
ثالثاً: قسم الأناشيد: قسهم مـختص بـالأناشيد الإسـلاميـة، وضعنا فيـه بعضـاً مــن المختــارات التـي اختيرت بعناية، ومـر اعاة مطابقتها لشروط الأنشودة الإسلاميـة. و نذكر بعض من الهنشدين الذين نشلدوا بـالأناشيد الإسلاميـة، منهم: الهنشد محمدل أبو راتب. الهنشد عماد رامي. ووكثير من الفرق الإنشادية: فرقة الأمواج الفنيـة.

' - سلسلة الأسر المسلمة، الأذكار (أذكار الصباح والمساء، وبعد الصلاة ، و أذكار النوم ، و أذكار متفرقة ) دار الحضيري للنشر والتوزيع ، ·سعاهـ ، بالمدينة المنورة ، 


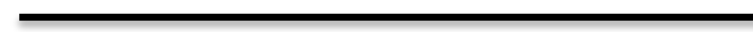

$$
\text { فر قة الخلود الفنية. }
$$

\section{وكذلك أناشيد جديلة:}

سامي يوسف أنشودة: أسماء الله الحسنى وغيرهم من المنشدين الذين لهم نذكر هم. (1) - (1)

\section{رابعاً: قسم الدروس والخطب الصوتية:}

يحتوي هذا القسهم على العديد من المقــاطع المتنووعـة الطريفـة الهـؤثرة وكذلك الأذان

\section{استفادة الدعاة من الإنترنت :}

قليلة هي الاختر اعات والاكتشافات التي غيرت وجه الحياة بشـكل جــذري

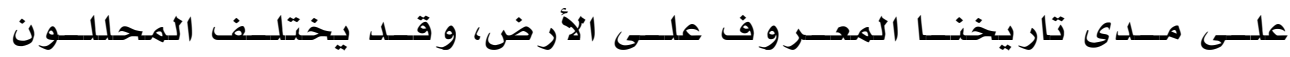

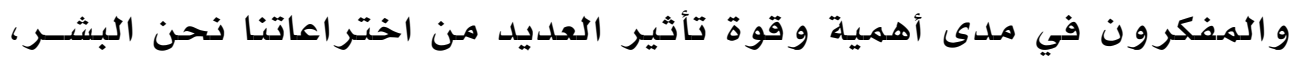

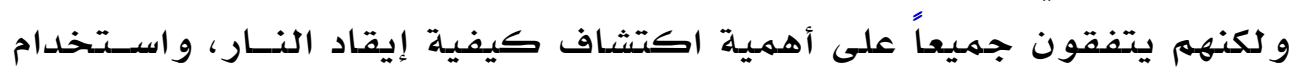

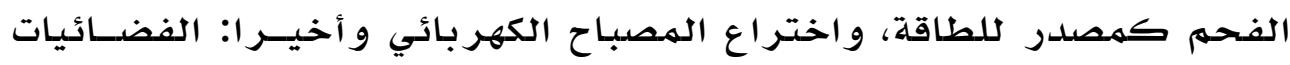

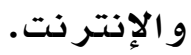

لقد أدى انتشار الإنتر نت و الفضائيات سر يعاً في جميع أنحاء العـالهم

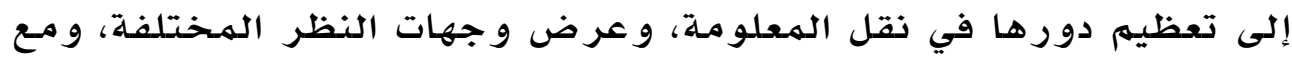

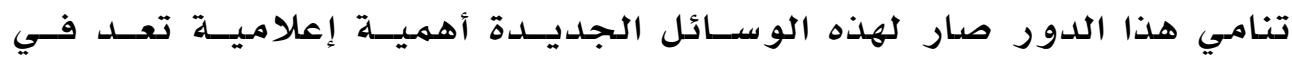

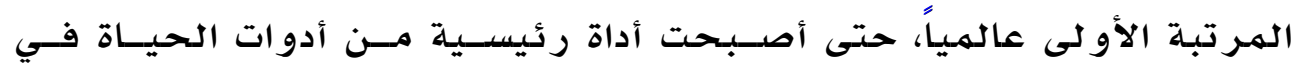

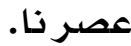


و منذ دخول الهسلـهين إلى هذا الهـجال، وجدت الدعوة آفاقاً جديدة لتنطلق

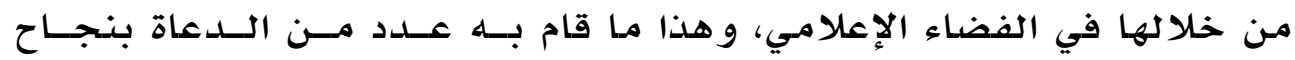
ملحورظ، خصو صاً في الفترة الأخيرة.

و أحب أن أوضح أن حصر الهسألة فـي حسلدود أشـخاص بعيـنهم لا تقارب الصواب؛ لأن النشاط الدعوي على الفضدائيات والإنترنت لهم يقتصـر الهر على دعاة بعينههم، بل هناتك مؤسسـات ضدخمهة تقوم بلدور دعوي متكامل على الإنتر نت، كموقع إسـلام أو لاين، وموقع الإسـلام اليـوم، ووكـذلكـ موقــع الشبكة الإسلامية إسلام و يب، وقنو ات: الرسالة و اقرأ و سهارت.

و من ناحية أخرى نجد أن الكثير من الدعاة لهم مسـاحة على شـاشــة الفضائيات، و لكن الاختتلاف من داعية لآخر يكمن في مدى فاعلية مـا يقـوم

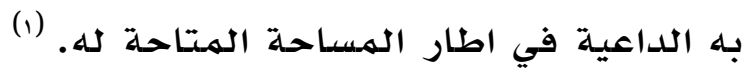
أسهمهت و سـائل الإعلام الحديثثة أيضاً فـي ابـراز عـدد مسـن العلهـاء و الدعاة الهـميزين، والذين كانوا لا يسهـع عنهم إلا القليل، و لا يعـر فهم الا من يترددون على دروسهم أو يحضـرون خطـبهم، و لكـن وســائل الإعـلام الححديثة منـحت الفر صـة لكثير من الناس كي يستفيلدوا مـن هؤلاء العلهــاء

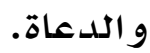




\section{المبحث الثالث}

\section{وسائل الدعوة عبر الأنترنت}

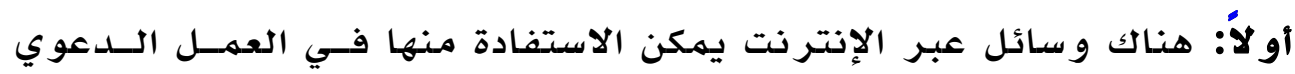

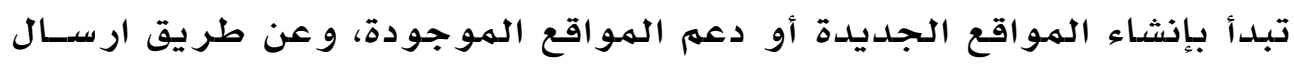

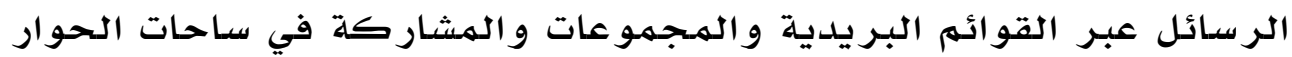

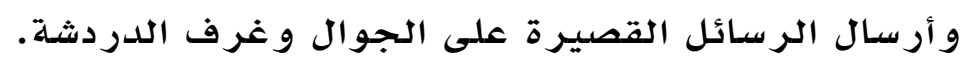

فبالإضـافة إلى الهواقــع الإســلامية التـي سـبق التحـــث عنهـا فـي

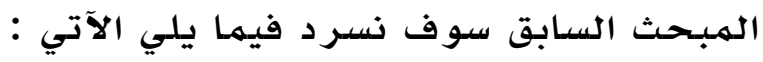

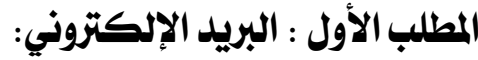

وهذا باب متسع للدعوة الـى الله تعـالى يمكـن اسـتخدامـه بارســال

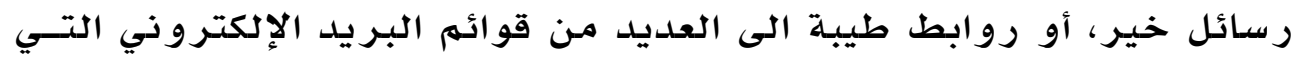

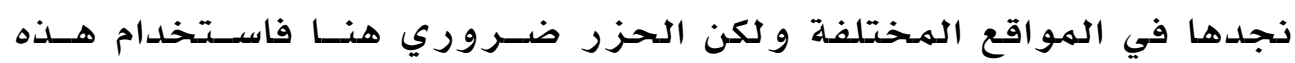

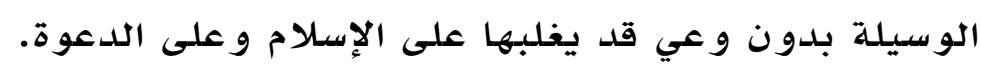

الالطلب الثاني : ساحات الحوار:

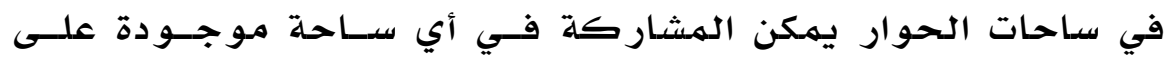

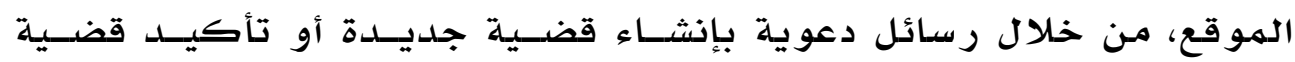

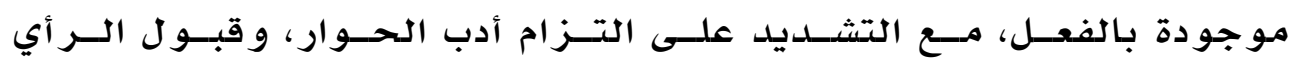

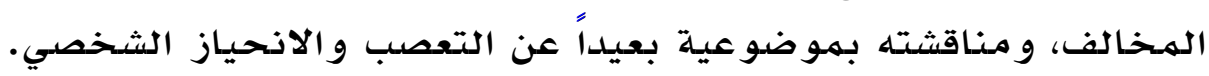

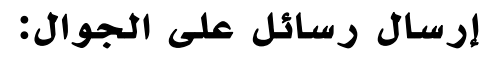
وسيلة مبنية على كلمات بسيطة و مـركزة ترسـل إلـى أرقـام يعـرف

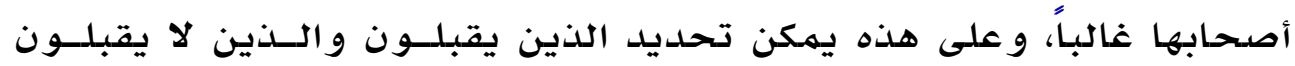

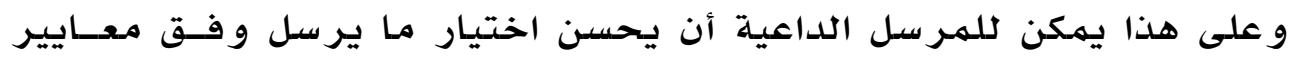

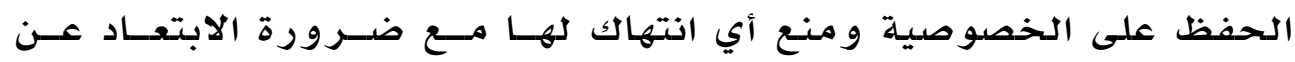


الر سـائل الشخصيـة التي تومسي الى مستقبليها أن الهـرسل يعنيـه هو شخصـياً

في أمـر يخدمهـ دون غيرهـ (1)

الفيس بو ك5

\section{المطلب الثالث ساحات المنتديات والنقاش}

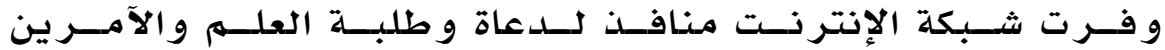

بـالمعروف و الناهين عن الهنكر، و الهصلحين من أبناء هــذه الأمسـة، لإبـلاغ غ

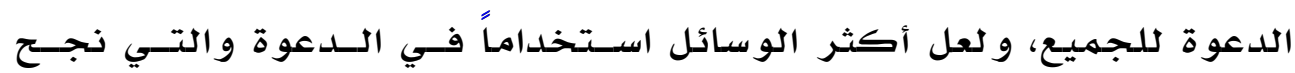

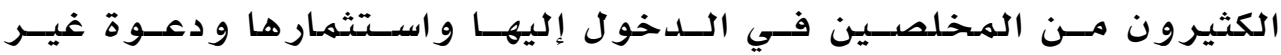

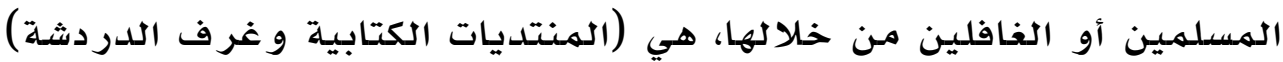
النوافذ الهامـة للدعاة فهي مصدر ضخمم للمعلومات و الخبرات في الهجـالات المسحددة التي توافق ميول ورغبات المستخدم، و مـجال متسـع لطرح الأفكار

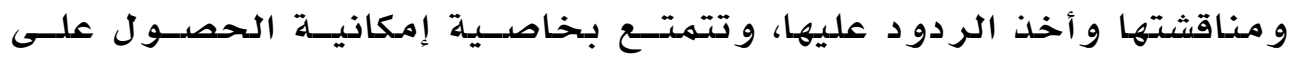
حلول لأي مشكلة من خلال طرحها في المنتتدى و من ثم ترقب الردود مــن المستخلدمين الآخر ين.

و الجدير بالذكر أن الهنتديات، الهناقشات فيهـا لا تنتهــي بانتهـاء اللقاء كها هو حاصل في الحوار الهبـاشـر بل أن الفكرة أو الهـوضـوع قـــ

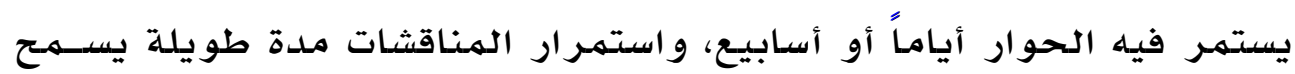
للمستتخدم بالبـحث عن إجـابات منافســه للهمواضـيع التـي طرحست ويسـهـع بصياغتها بشكل جيد قبل طرحها وليس بالشكل الهـرتجل الذي يكون عليـــ الحـوار المبـاشـر • يهكـن الاسـتفادة مــن المـنتـلديات فـي الـــعوة إلــى الله بالمشاركة الفعالة و التي تنقسم إلى الأقسسام الآتيـة :

أولاً: الهشاركة الفعالة في الهنتديات الهوجودة على الشبكة عن طريق:

$$
\text { الشبكة العنكبوتية }
$$

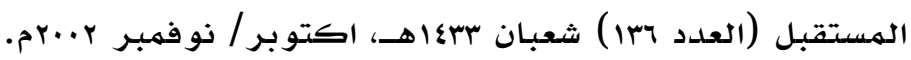


طرح الهواضيع الجيدة والاستعداد لأي مداخلة أو سؤال.

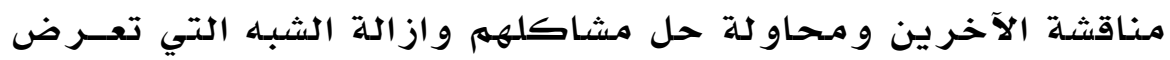
لهمه.

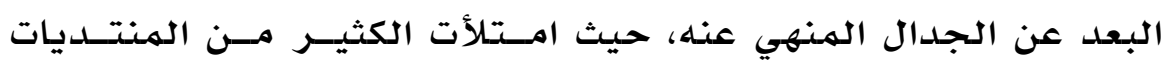

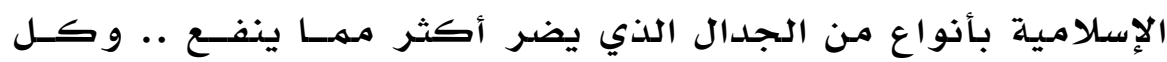

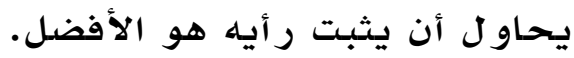

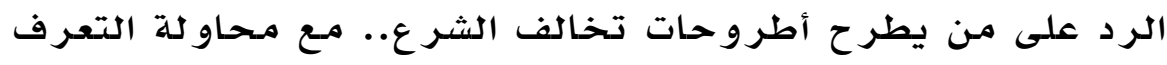

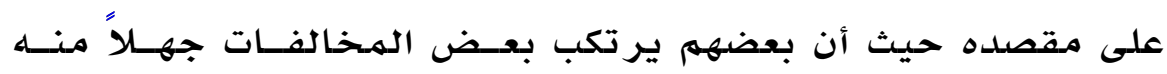

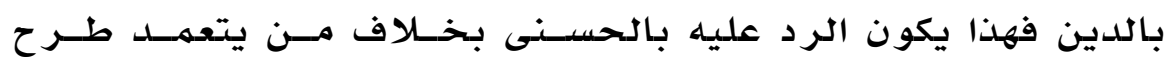

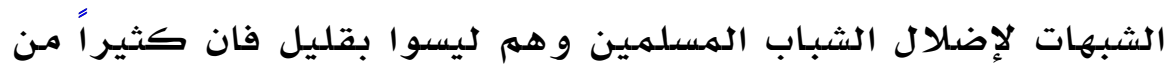

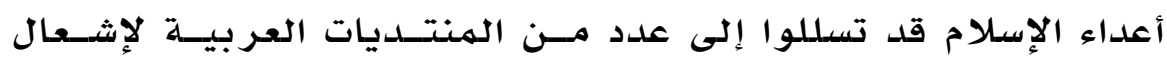
الفتنة بين المسلمين و تشكيكهم في دينهم.

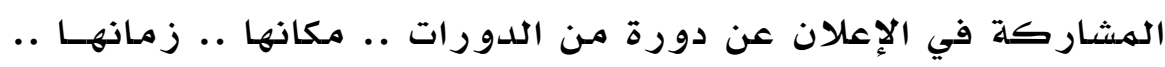
أو محاضرة أو ندوة من الندوات الإعلات دورة من فيتعرف الدورات الناس عليها.

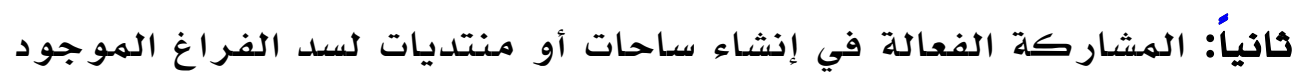

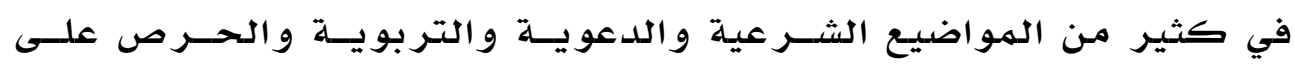

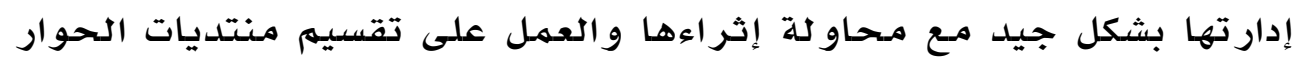

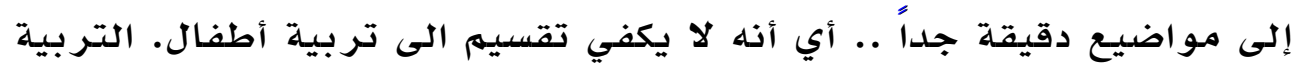

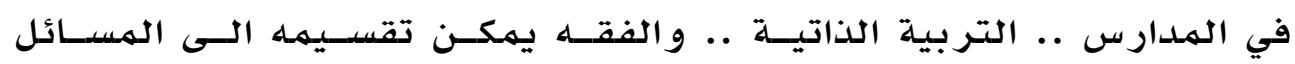

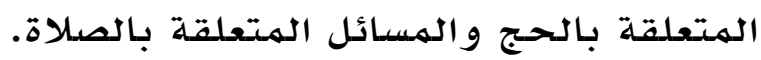

ثالثاً: الحوار الهبـاشر (Shat) أو مـا أطلق عليه بلغــة الإنترنـــ العربيـة

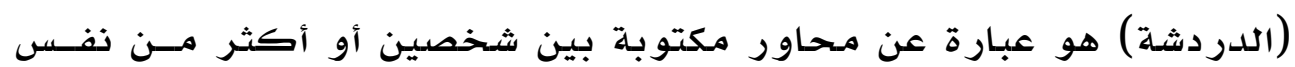

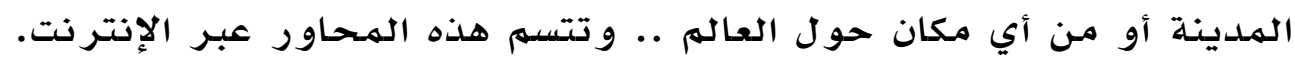

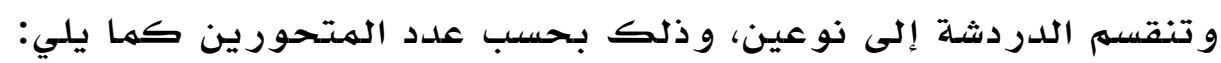


ا. دردشة تتهم بين شخصين فقط يحاور كل منهمـا الآخـر مسن خـلال

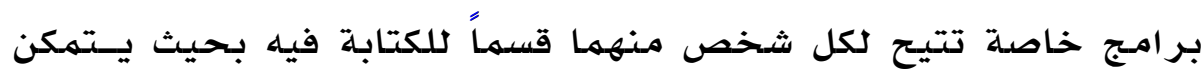

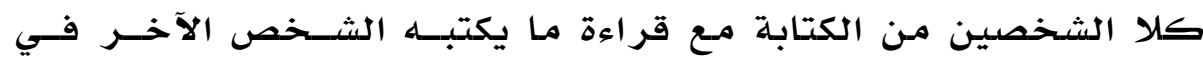

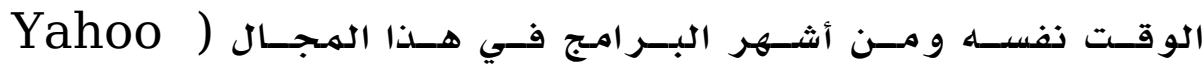
(Messenger r. : دردشة لعدة أشخاص حيث يمكنهم التحدث معاً في نفس الوقت كما

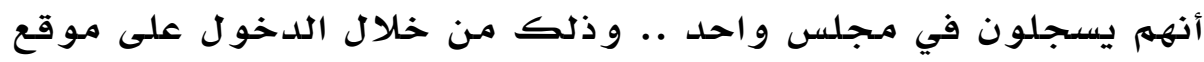
معين.

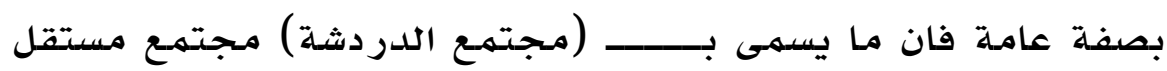

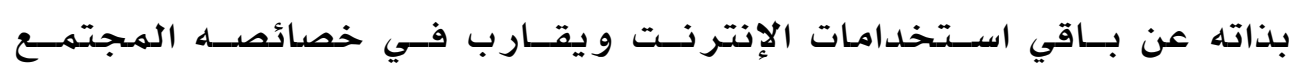

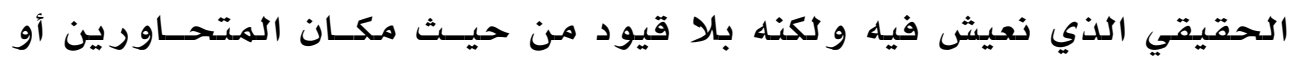

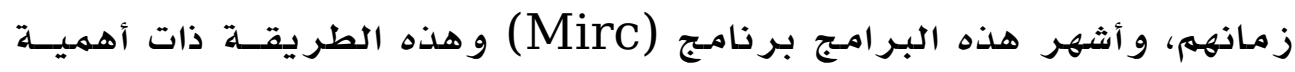

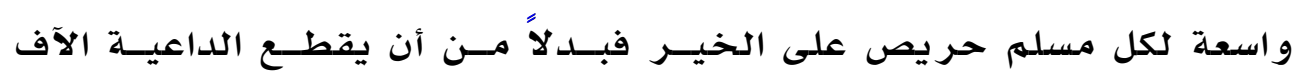

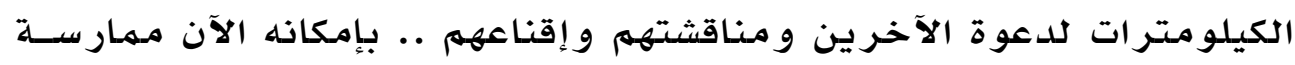

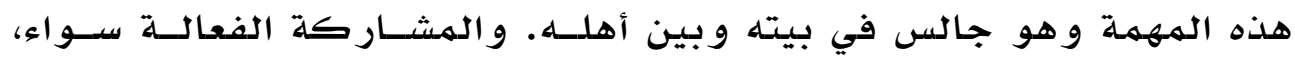

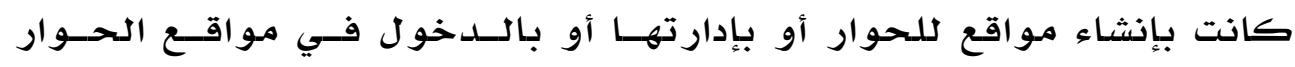

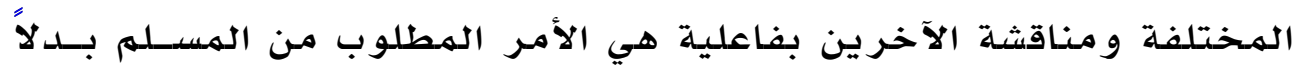

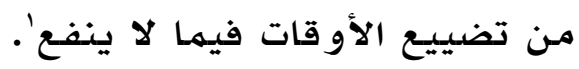


المبحث الرابع :الماريع الاستثمارية الدعوية على شبكة الإنترنت

\section{المطلب الأول مشروع المملكة العربية السعودية:}

لقد خص الله سبحانه و تعالى الهملكة العربية السعودية بخصـائص

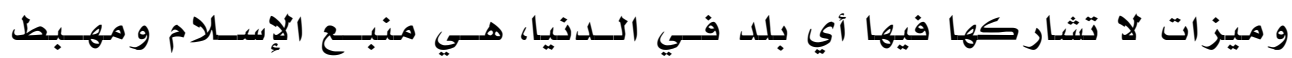

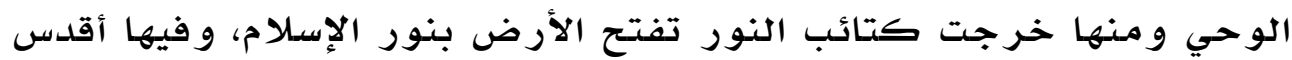

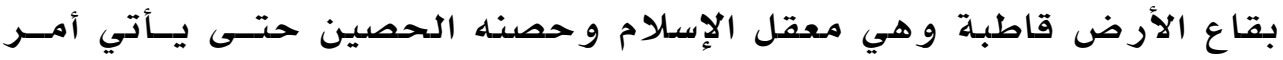

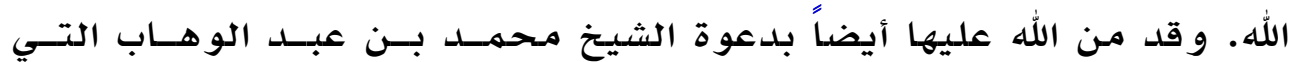

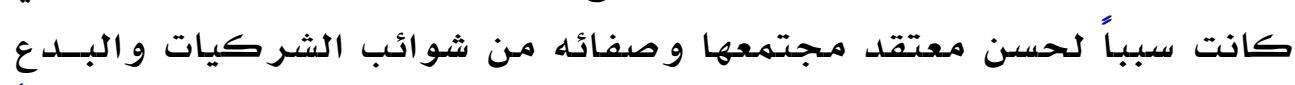

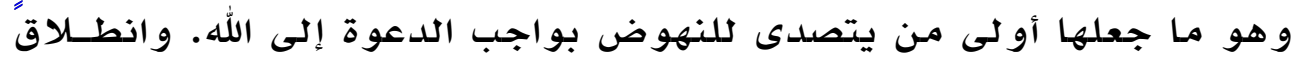

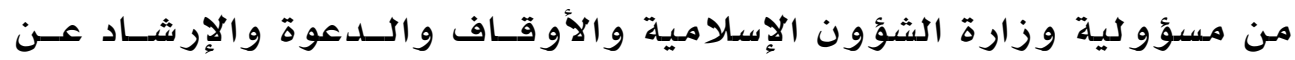

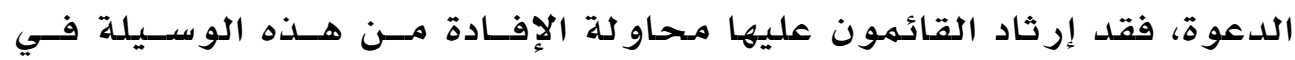

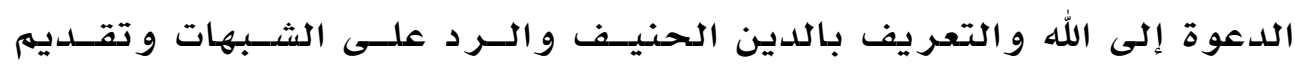

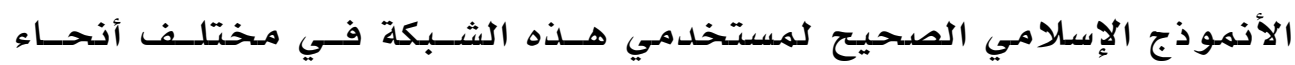
العاله.

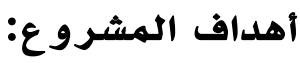

ا. الدعوة إلى دين الإسلام الحنيف، و بيان حقيقته وحاجة البشر إليه.

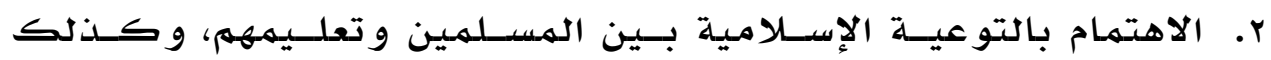

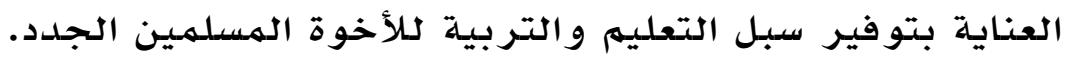

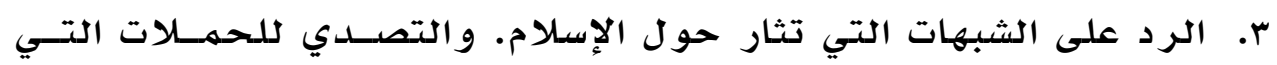
تشن عليه من قبل أعدائه.

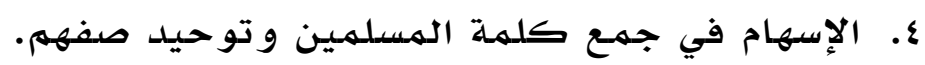

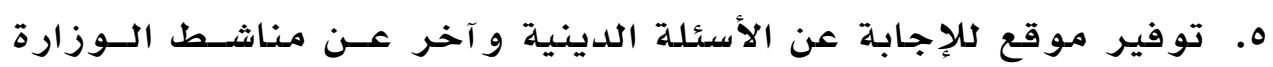

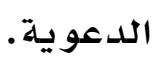

الوسائل التي تخص المشروع: 
ا. استكتاب العلهــاء و الهفكـر ين و الهختصــين فـي الــدعوة و الشـؤون الإسلا ميلة.

r. و ضـع إصدارات الوزارة و الهـركز مـن الكتــب والبـحـوث و النشــرات و المهالات وترجمات معاني القر آن الكريهم و الحديث النبـوي الشريف

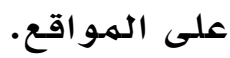

ب. تحديد الشبهات المثارة حول الإسـلام باللغـات المـختلفــة ثـم الـرد عليها.

ع. نشر التعليقات عن أهم الأحداث و القضسايا الهصـير يـة بالنسـبـة إلـى الإسـلام و الهسلمين، وتقلديهم التحليل الهلائم لها من وجهة شر عية. ه. اختيار نماذج الفتاوى الهعاصرة لأبرز العلهاء الهعرو فين باتبـاعهم منهجج السـلف الصسالح وإبرازها على الهـوقع. 7. توفير أكبر قدر مـن الهعلومات و الإحصداءات الإسلاميلة يفيـد منهـا الههتمون كعناوين مكاتب الدعوة و مـر اكــز البحــوث و الهنظمــات و الجهعيات الإسـلاميلة و الهساجد و غير ذلك. V. تلقي الاستفسار ات ودراستها و إعداد الردود د عليها. (1) برنامج بالتولك على شبكة الإنترنت:

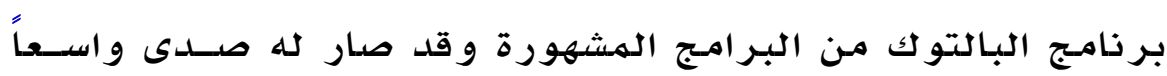
في الفترة الحالية وبخاصة بعدما استغلـه أهل الخيـر في نقـل الـدرووس العلهية إذ أن من أبرز خصائص بر نامـج البالتو ك هو أنه عبارة عـن غرفـة صوتية داخل نطاقات مختلفة فهن النطاقات مـا يختص بأوربـان ومنهــا مــا يختص بآسيا و منها ما يختص بالعرب.

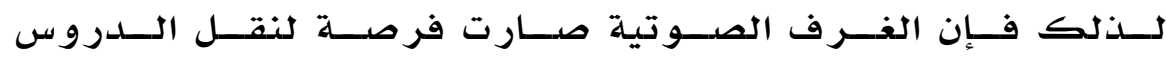
و المـحاضـرات على الهواء مهما كان له أبلـغ الأثـر فــي نفـوس مسـتخدمي

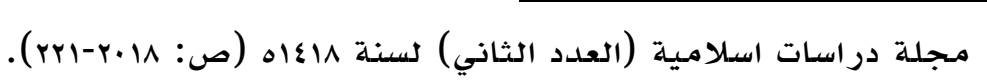


الإنتر نت و بخاصـة من يقومون خسارج بـلاد الإســلام و المسـلمين وومسن لا يتسنى لهم تحصيل العلهم الشرعي و الجلوس فوله في حلقات العلهم.

\section{البالتوك في خدمة الدعوة:}

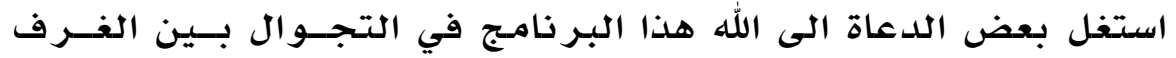

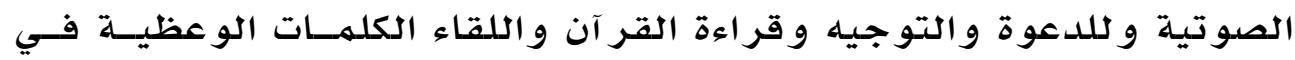

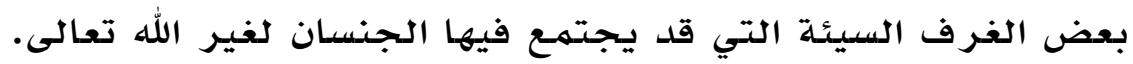

وقد حصل بفضل اله تعالى بين هذه الجوالات الدعوية خير كثيـر

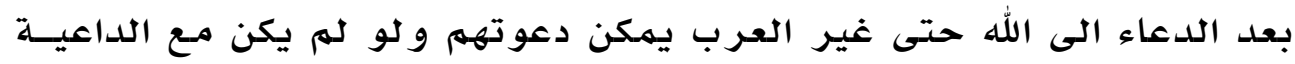

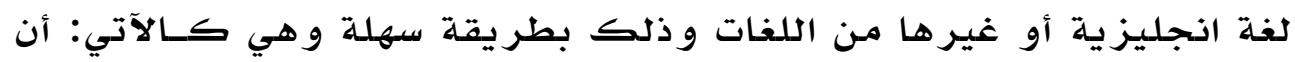

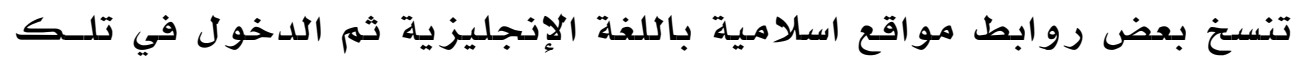

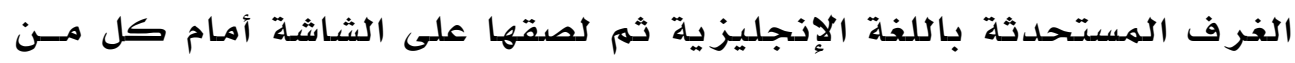

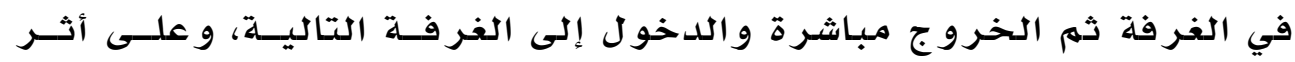

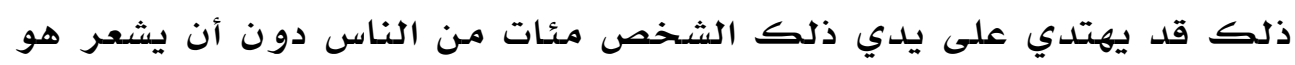

بذ بك. (1) 
الاطلب الثاني : إسلام شاب عن طريق الإنترنت:

شاب نيوزلني اسمهـ أحمد أسلهم منذ ثلاثة سنوات وو الداه لا يعلمـان

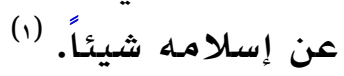

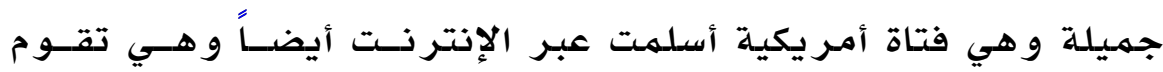

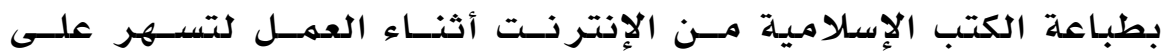

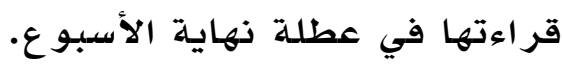
و كذلك أسلهم شاب بر يطاني عمره 10 عام.

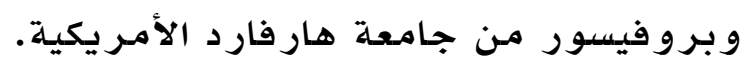
هؤلاء على سبيل الهثال فقط لا يحصون عدداً. إسلام القس المصري اسحق هلال مسيحة: ماخوذة من الإنتر نت: الاسم: اسحق هلال مسيحة. الهمنة: راعي كنيسة المثال المسيحي ورئيس فخـري لجمعيـات خـلاص النفوس الهصرية بأفريقيا و غرب آهرئ آسيا.

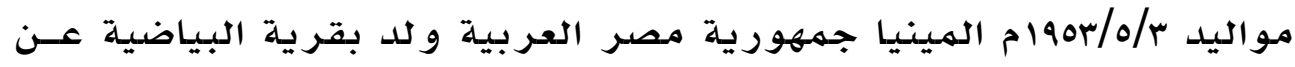

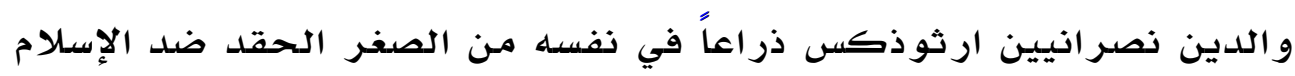
و المسلمين.

يقول (حين بدأت أدرس حياة الأنبيـاء بـدأ الصـراع الفكـري فـي داخلسي

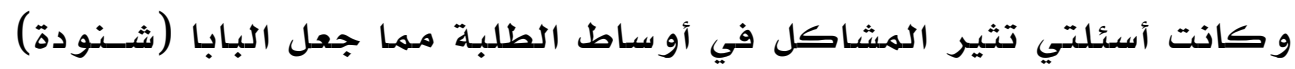

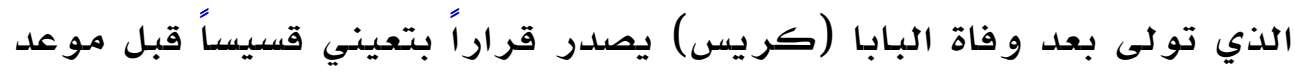

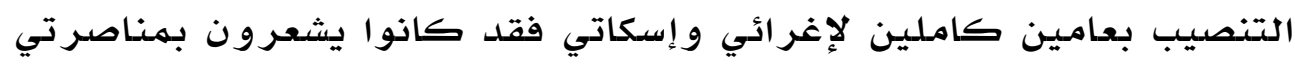


للإسلام - مـع أنه كان مقرراً ألا يتهم التنصيب إلا بعد مرور تسـع سـنوات من بداية الدراسة الدلاهو تية.

\section{لهدايتي قصة:}

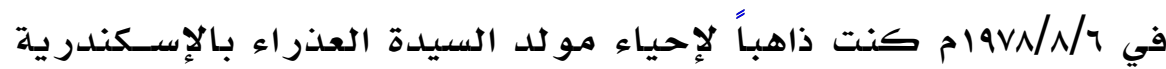

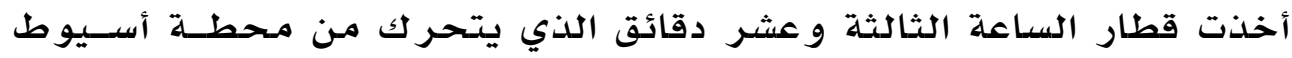

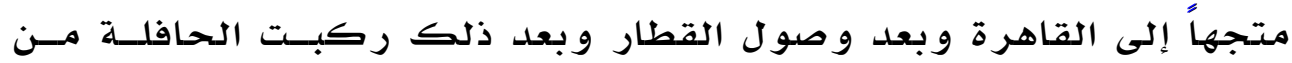

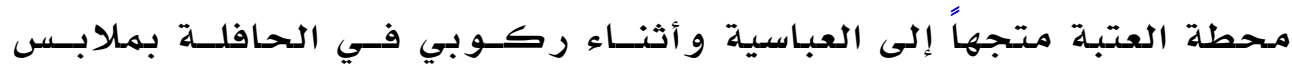
الكهنوتية و صليب يزن ربع كيلو من الـذهب الخـالص و عصساتي الكريـر

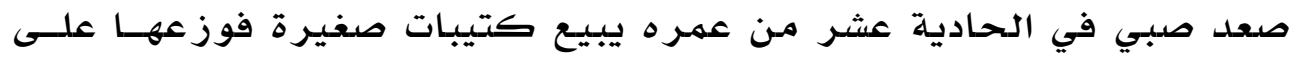
كل الركاب ما عدا أنا وهنا صار في نفسي هاجس لهم كل الركاب إلا أنا

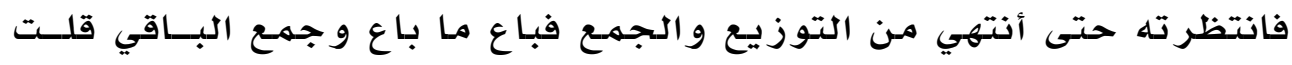

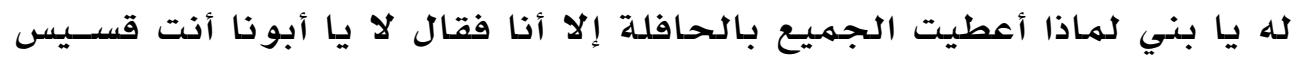

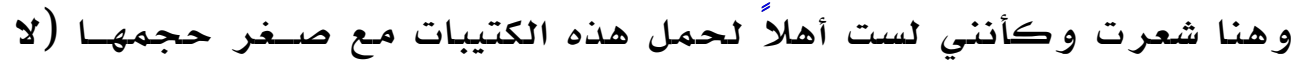

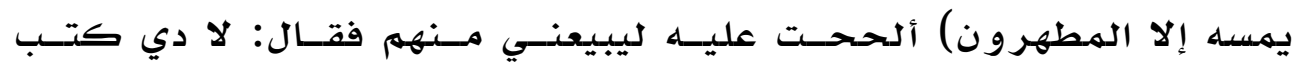

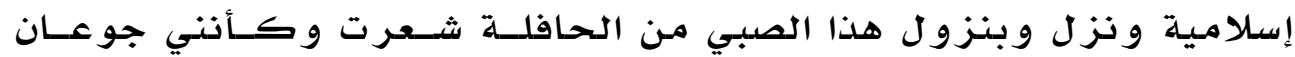

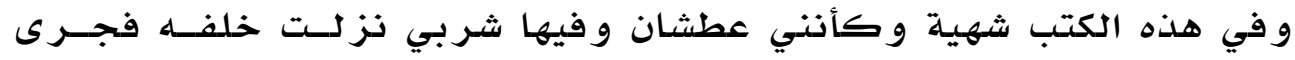

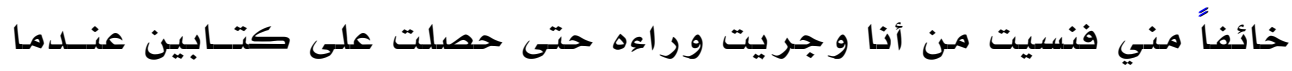

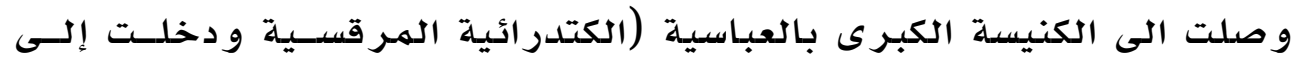

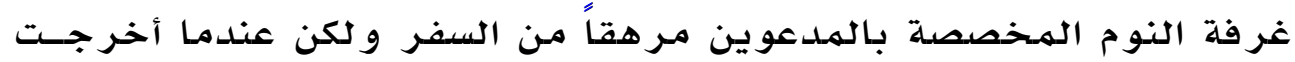

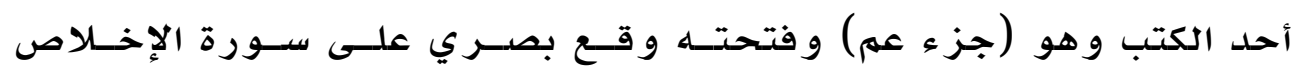

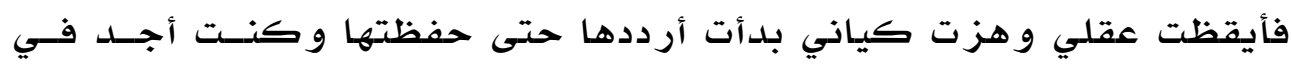

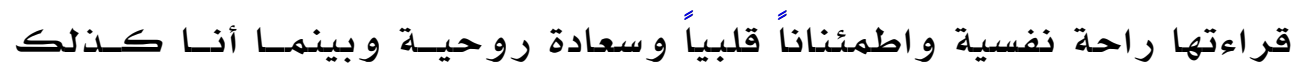

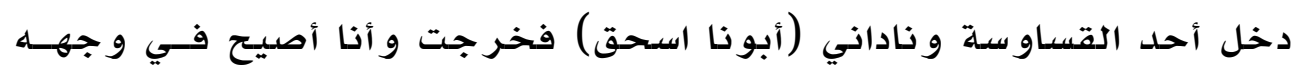
(قل هو الله أحد) دون شعور مني. 


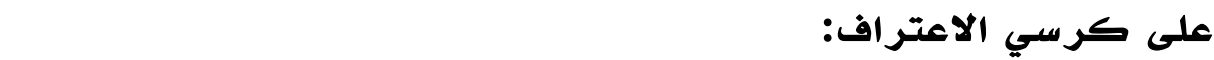

يقول ووفي يوم الأحد عندما ذهـب إلـى الإسـكندرية لإحيـاء مو لـــ

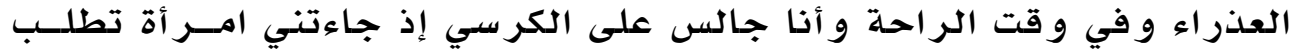

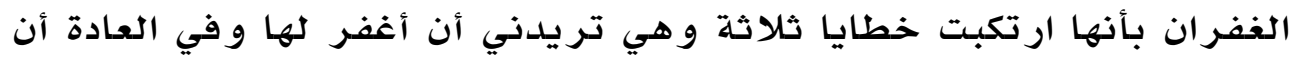

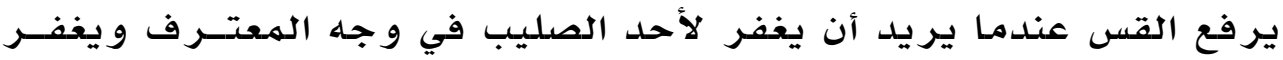

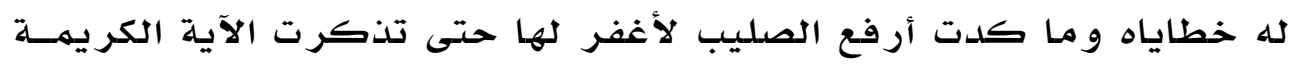

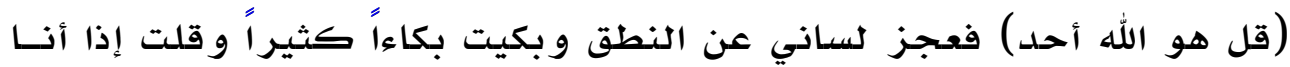

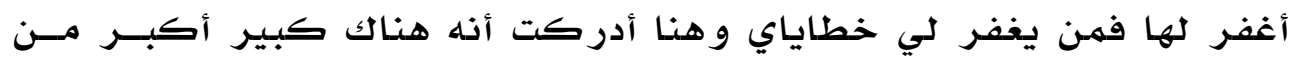

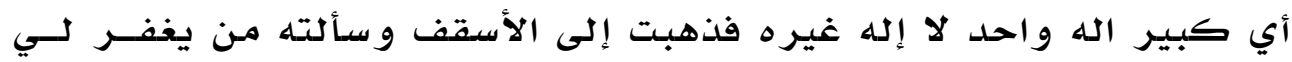

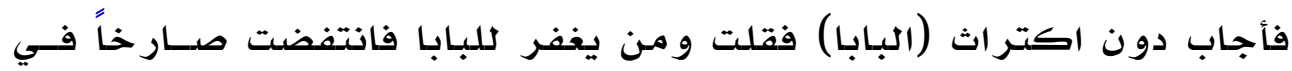

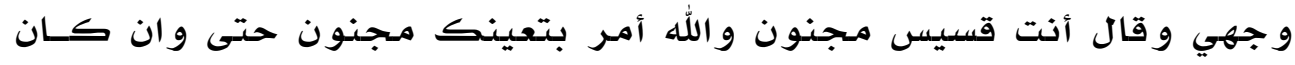

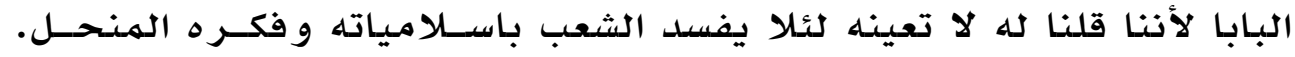

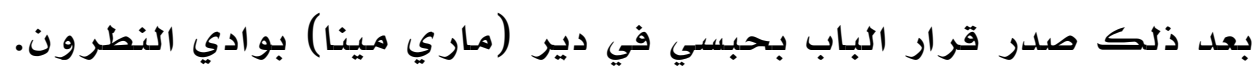

$$
\text { كبير الر هبان يصلي: }
$$

يقول اسحق أخذوني إلى كبير الرهبان لتأديبي وتقديم النصـيحة

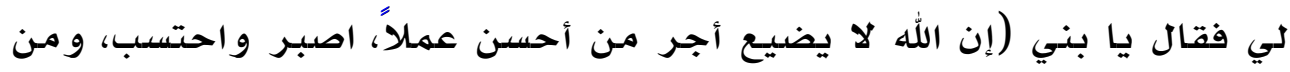

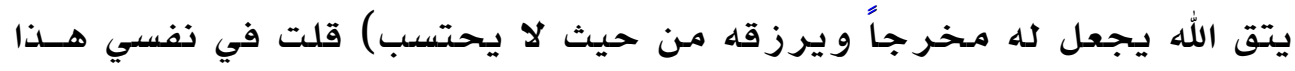

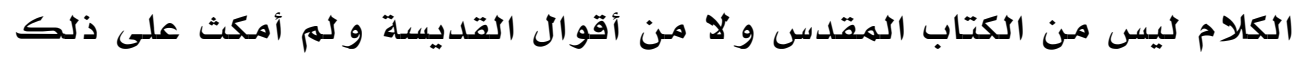

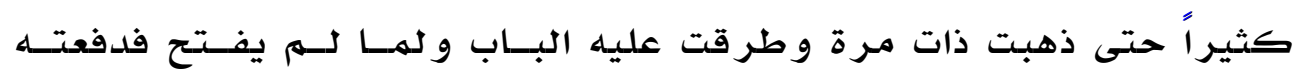

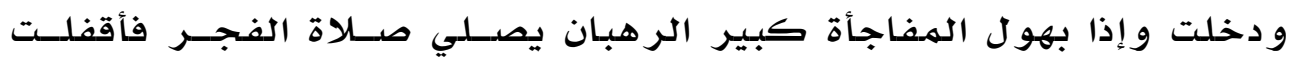

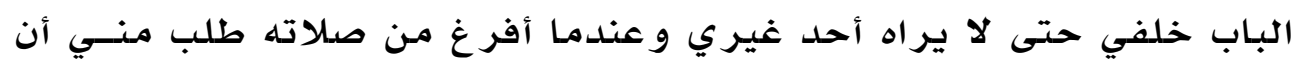

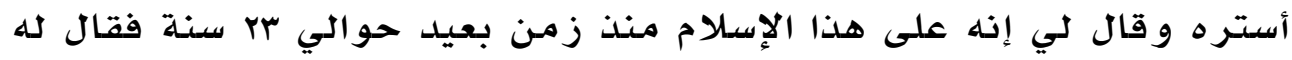

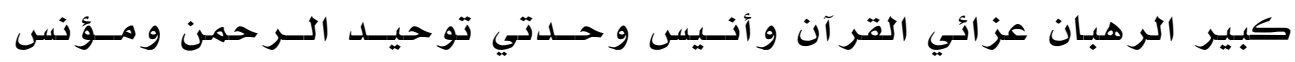

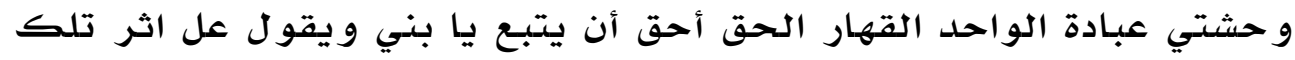

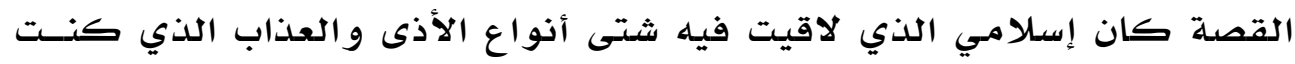

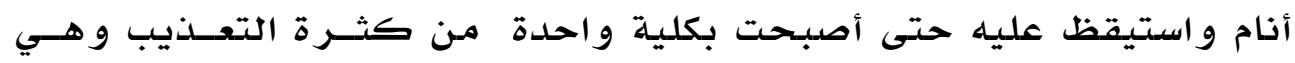
TAᄉ 
اليمنى و يوجد بها ضيق في الحالب بعد التضخم الــذي حصـل لهـا بقــدرة

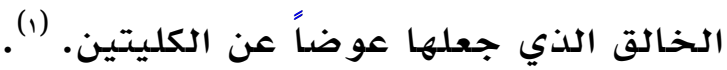

الالطلب الثالث: المحاذير من بعض مواد الإنترنت

الإنتر نت محظور ات شر عية ودعوية

أولاً : المحظورات الشر عية :

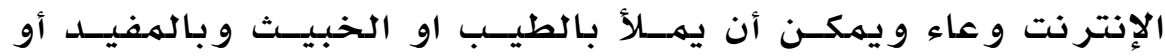

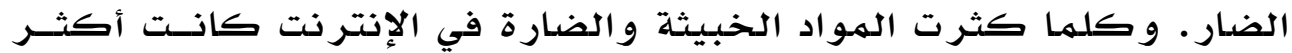

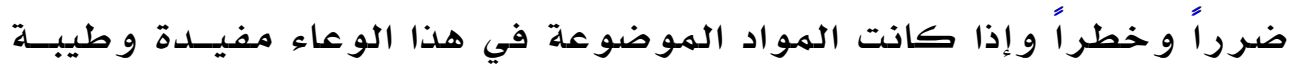

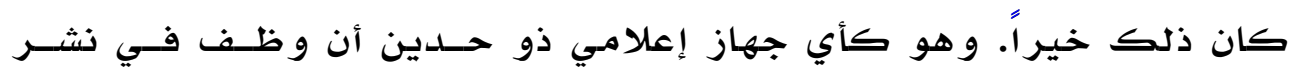

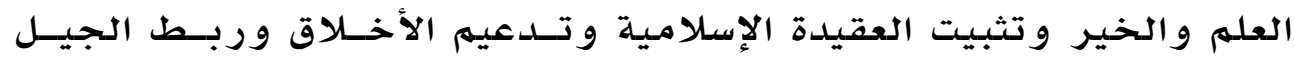

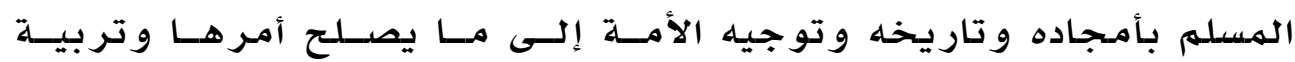

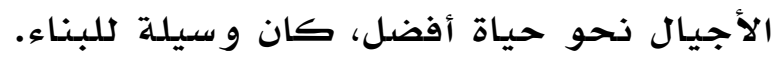

و إذا استعمل للفسـاد والانحر اف و نشر الميو عة والانحلال و تحويـل

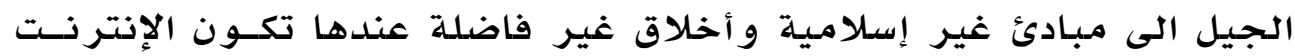
وسيلة هدم لا بناء.

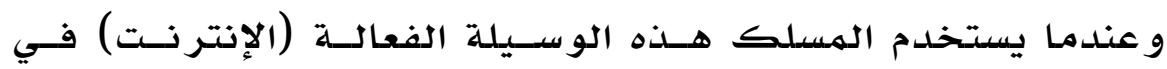

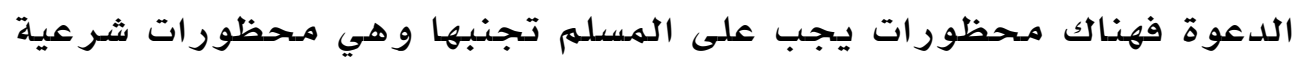
و محظور ات دعوية

أو لاً: الهحظور ات الشرعية:

تتلخص في الآتي:

(حرام النظر)

موقع رجال و نساء أسلهو - قصتي. 
قال رسول الله (صلى الله عليه وسلهم) (العينـان زناههـا النظـر ) (1)

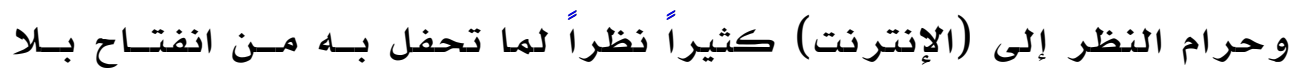

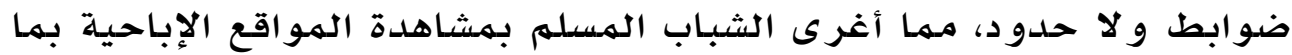

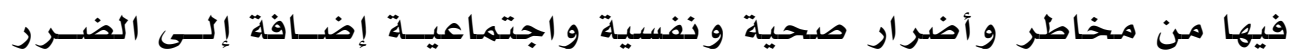

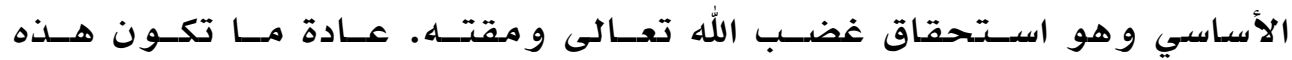

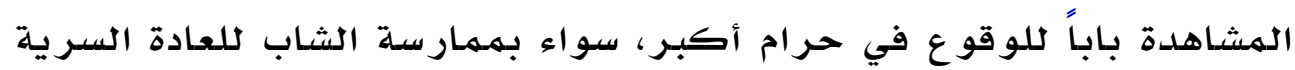

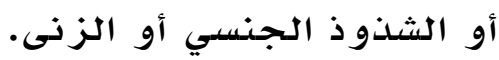

\section{(Shat)}

حر ام الدردشة، للأسف كثير اً، نظراً لهــا تحفـل بـهـ مــن إغــر اءات

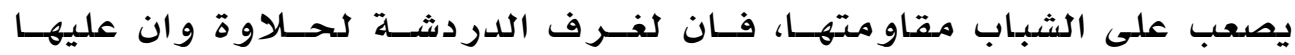

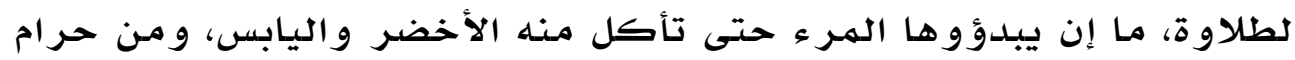

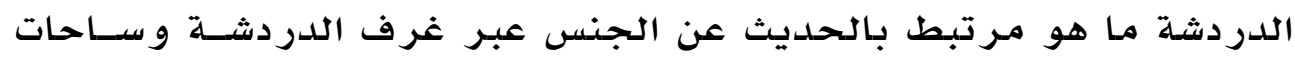

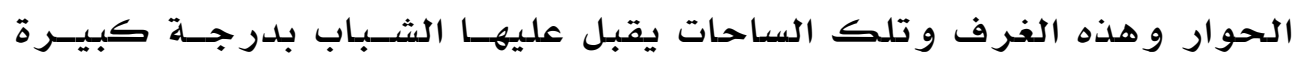

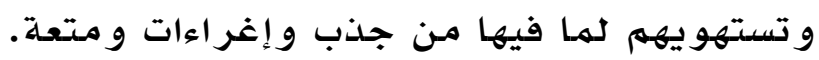

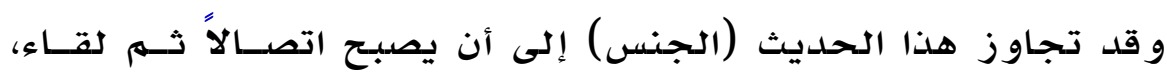
فالو صول إلى الهاوية و العياذ بالله تعالى.

و من حر ام الدردشـة كذلك الكذب و الادعاء الـذي يمارســه الكثيـر

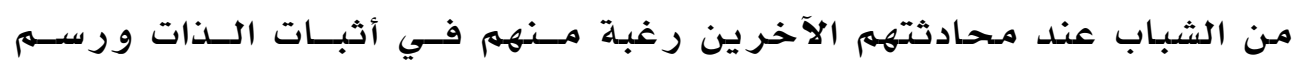

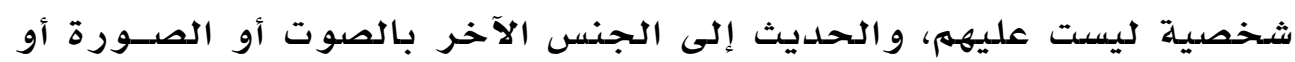
بحديث فيه إثارة أو أغر اء. 
اختر اق الخصوصية:

هناك من امتتلأ بريده الإلكترو ني برسائل لا يعسرف عـن أصسحابها

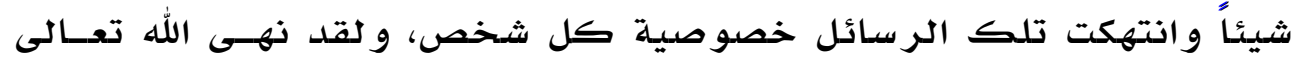

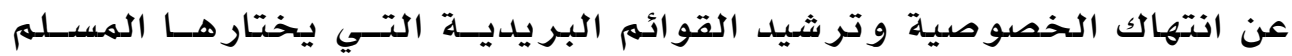

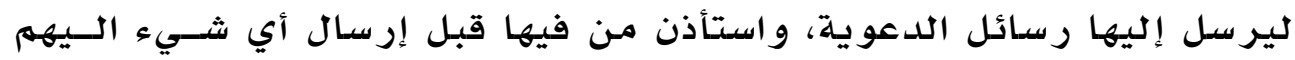

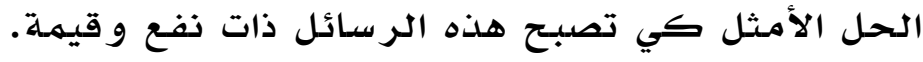

\section{الإلهاء عن الصلاة والفروض:}

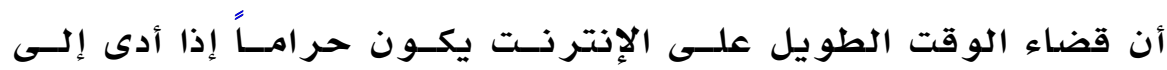

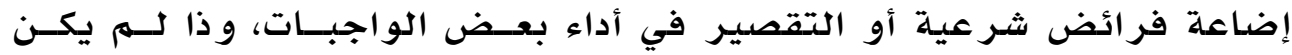

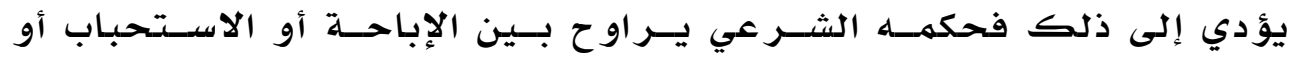

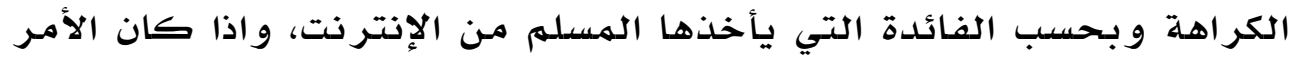

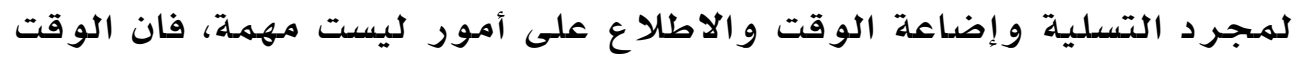

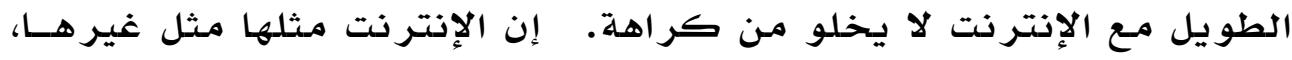

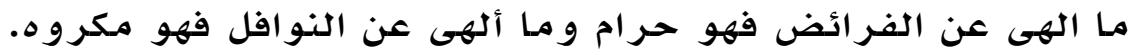

\section{تضييع الأو قات:}

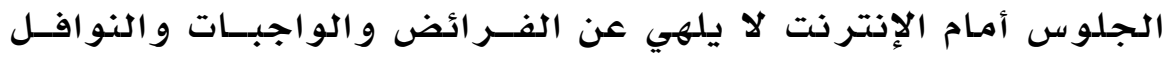

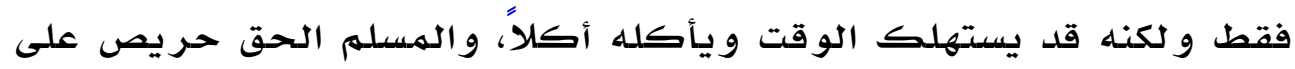
وقته فلا يضيعه في ما لا ينفح.

\section{عدم الالتزام بادب الحوار:}

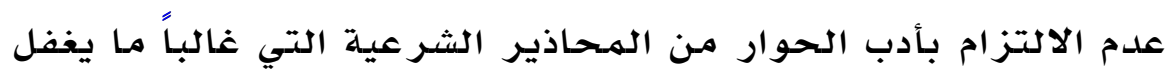

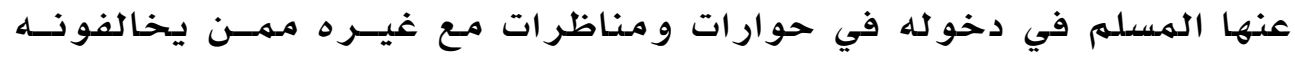

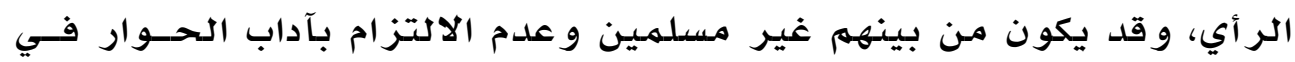

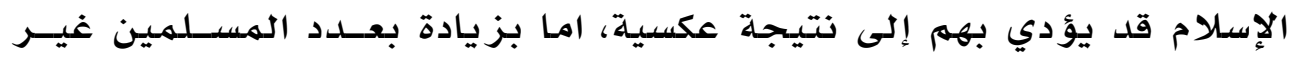


الملتزمين عن الإسلالام، أو بنفور غير المسلمين عن الإسلام، وتغلدو مسـألة

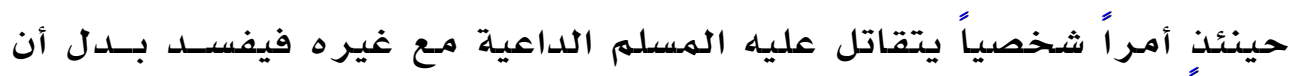

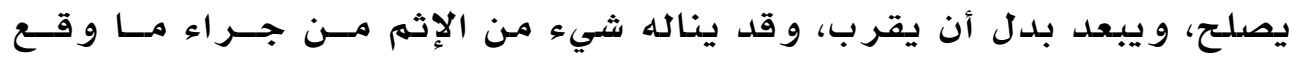
فيه.

لذلك على المسلهم الالتزام بأدب الحوار مـن صسـدق ونيسة صـالحسة

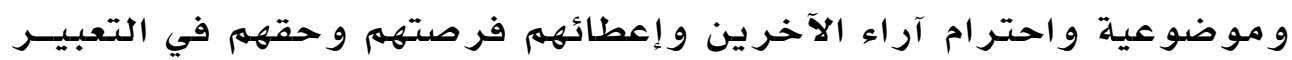

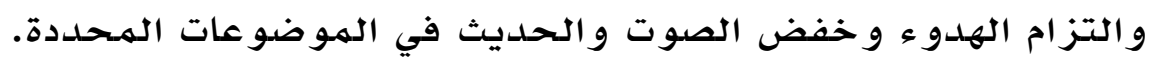

\section{ثانياً: المحطور ات الدعوية:}

والمحظورات الدعوية على شبكة الإنتر نت كثيـرة و يمكـن تقسـيهمها إلـى ثلاثة أقسام:

أ. محظورات خاصدة بالداعية.

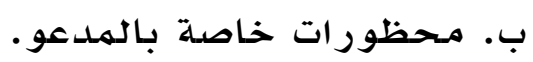

ج. محظور ات خاصة بالوسيلة.

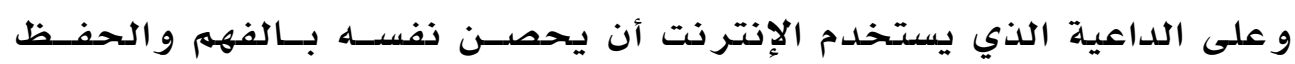

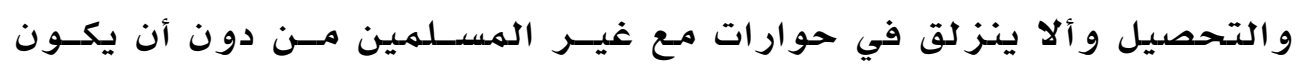

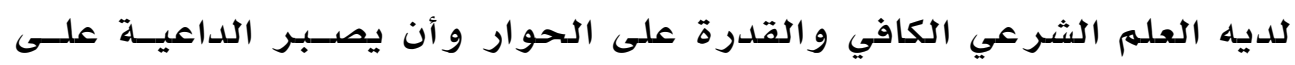

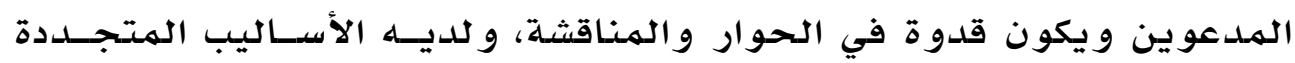
و ألا يكون نهطاً تقليدياً)

أمـا المـحاذير في المدعوين فضرورة مـراعاة مـرحلــة العمريسـة فـلا

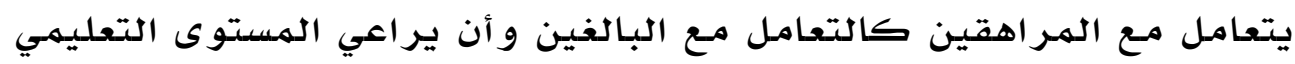

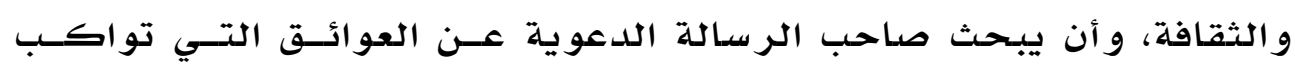
رسالته ويز يلها.

. http://www.khayma/alshabab\%r.and \%.r.rsael.htm 


$$
\text { اتضح إخواني و أخو اتي الشبـاب }
$$

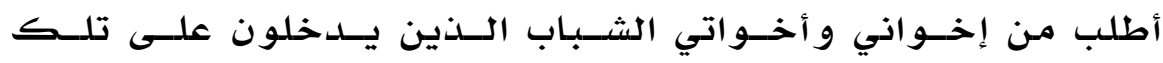

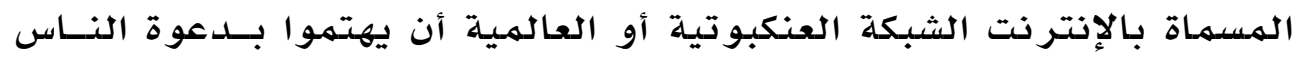

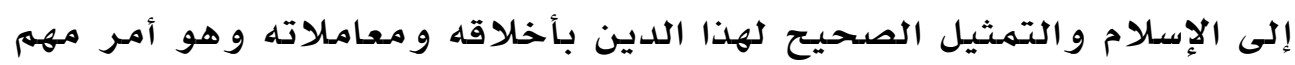

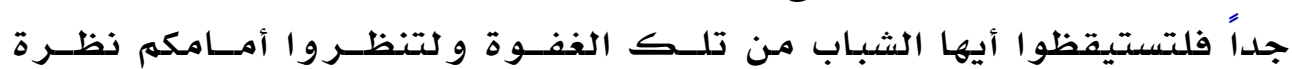

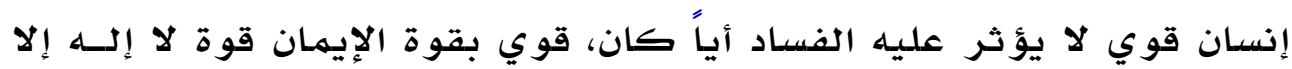

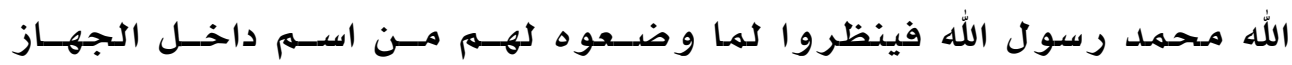
و ليقولوا لهم نحن أقدر على إفساد ما تزرعون لنا. و لا نامت أعين الجبناء ولهاء

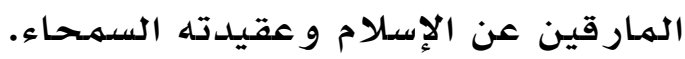


الخاتمة:

الحمهد لله نحمده على آلائه و نشكره على نعمـائه و أحمد الله كثيـراً الذي و فقني أن أته هذا البحث حتى يخرج بهذه الصدورة . ان استثهار هذه الوسيلة في الخير و فيما يرضي الله تعالى و بالبعد عما حرم الله تعالى مهـا

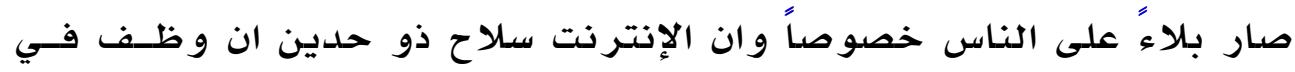
نشر العلم والخير وتثبيت العقيـدة الإسـلاميـة كــان وسـيلة للبنــاء. وان استخدام للإفسساد والإنحر اف و نشر الميوعة و الإخلال كان وسـيلة هــدم لا بناء. و من أهمر النتتائج

النتحائج:

ا. أي تحر ك على الإنتر نت يهدف نشر الخير للنـاس دائماً يدخل تحست بند الدعوة إلى الله. r. الدعوة إلى الله لا تقتصر على الحديث والآيـة التي يتهم نشـرها عـن طريق الإيميلات بل إن هذا العصر هو عصر التسويق والابتكاريـة. ". و سـيلة الأنتر نت تعتبر مـن الوسـائل الحديثــة التـي فتحــت مـجــالاً

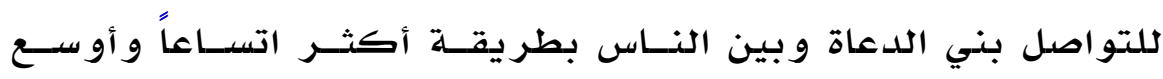

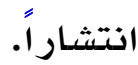

ع. انتقال الخلافات الفكر يـة بين بعض الدعاة إذـى شـاشـات الفضـائيـات و مواقع الإنتر نت وتبادل الاتهامات فيها بينههم، وذذلـك علـى مـر أى و مسهـع مـن النـاس، مهما يفقد الناس الثقة في بعض الدعاة، ويربـك البعض الآخر ، فلا يعرف الصواب من الخطأ.

التو صسيات:

ا. فعلى شباب الإسلام أن يضعوا أعينههم على تلك الوسيلة حتى يسلهم على أيديهم الكثير من الناس فليدعوا عبر الإنتر نت الى العقيـدة الإسـلاميـة

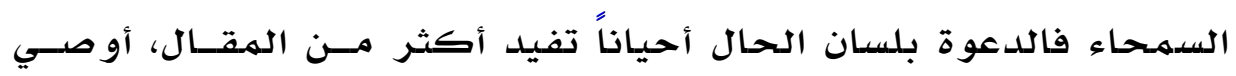
الشبـاب من الانزلاق في برك الضدلال التي يحيكها لهـم أعسداء الإسـالام 
و يقدمونها لهم سهلة رخيصلة في ثمنهـا و لكـن عاقبتهـا وخيهــة فهـي الانحر اف والهدم لكل ما بناه وما كان سوف يقوم ببنائه r. كما يجب التوسع في نشر الدعوة وو صول صوت الدعاة السى جههـور

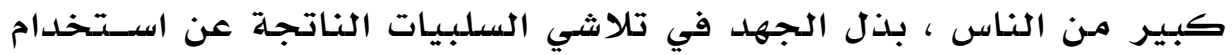

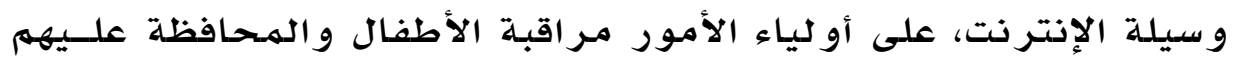

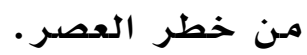

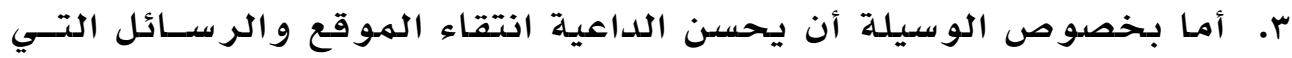

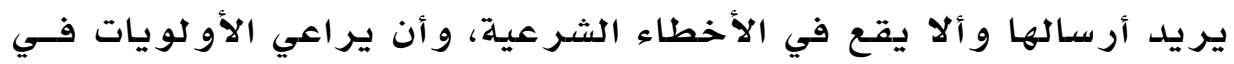

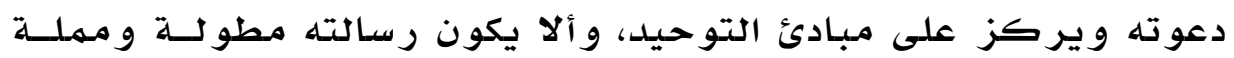
أو قصيرة جداً لا تفهه.

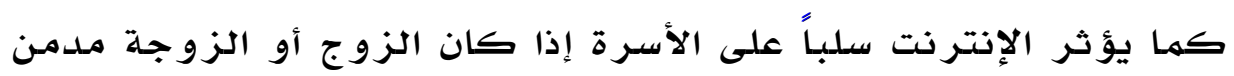

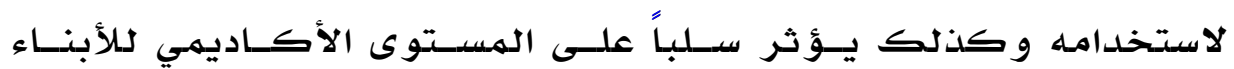

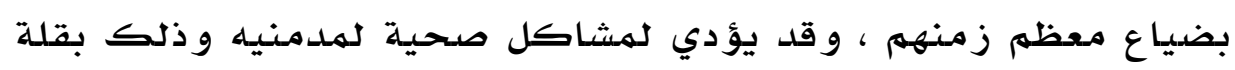

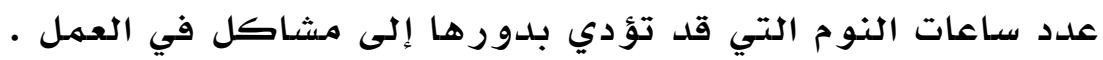

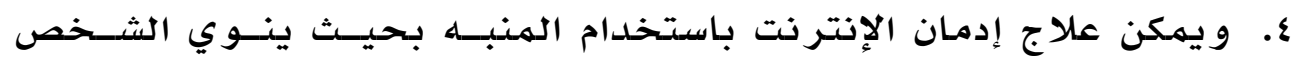

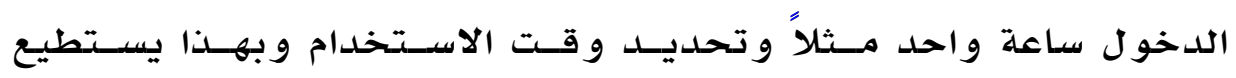

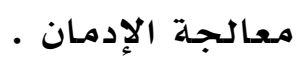

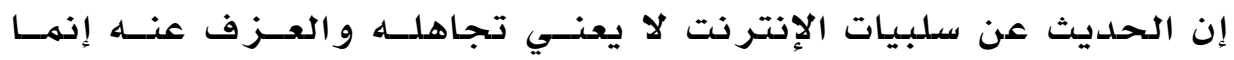

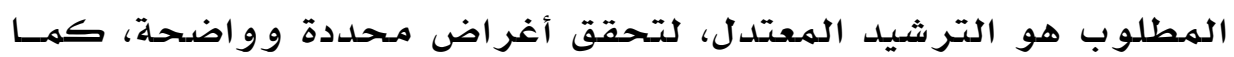

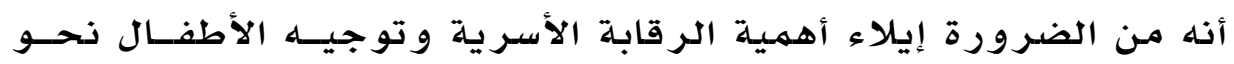

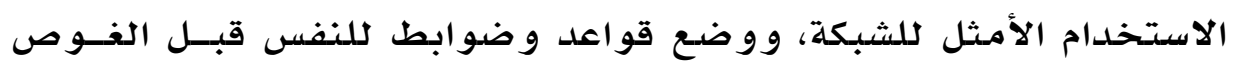

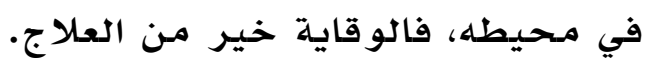

مجلة المستقبل (العدد بrا)، شعبان rrعا، أكتوبر / نوفمبر r...rم. 
ا. مصطفى السيد ، دليلك على شبكة الإنتر نت ، طم ع.بrم ، النشر القاهرة.

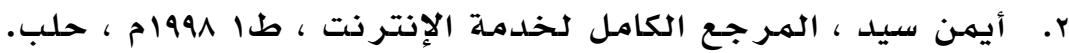
r. حلهي ساري ، ثقافة الإنتر نت ، مجدلاوي للنشر و التوزيـع ، عمــان - الأردن،

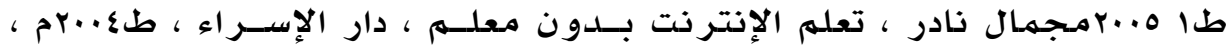

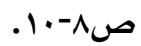
ع. الغر يب زاهر ، الكمبيوتر والإنترنت في التعليهم ، طا 1999م ، الــدار العربيـة للعلوم

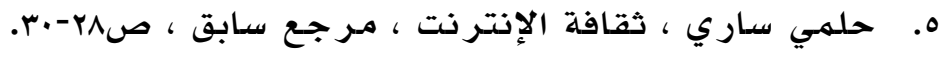
ج. عبدالله بن عبدالعزيز المـوسى ، مقدمة في الحاسب والإنتر نت ، مرجـع سـابق، صטגדr-rV. V. علي محمد رحومسـة ، الإلإنتر نـت و المنظو مسـة التكنو إجتماعيسـة ، طا يو ليـو

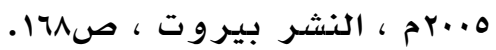
^. علاء الدين عبد الرزاق وحسين عبد الرزاق ، شبكات الإدارة ، دار و ائل للنشر

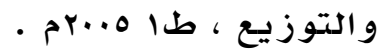
http//www:mpr.guran-net .9 •ا. سلسلة الأسر المسلمهة ، الأذكار (أذكسار الصـباح و المسـاء، وبعـد الصـلاة ، و أذكار النوم ، و أذكار متفرقة ) دار الحضيري للنشر و التوزيع ، ·بعاهـ ، بالمدينة المنورة

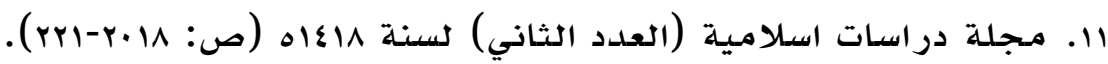
rا. الشبكة العنكبوتية الإنتر نت (ص: عه)، الجزء الأول ل.

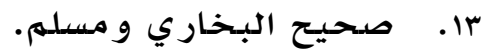

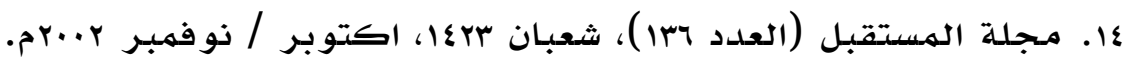
المواقع على الإنترنت:

\section{WwW.saaid.net .I} r. موقع رجال ونسـاء أسلـموا. r. صيد الفو ائد - معالم دعوية. الكاتب بدر بن نادر المشاري. 